\title{
Heyelan Duyarlılık Haritalarının İstatistik ve Makine Öğrenmesi Teknikleri Kullanılarak Üretilmesi: Taşlıdere Havzası Örneği (Rize)
}

\author{
Producing Landslide Susceptibility Maps Using Statistics and Machine Learning Techniques: \\ The Rize-Taşludere Basin Example
}

\section{Arif Çağdaş AYDINOĞLU1 ${ }^{1}$, Gehver ALTÜRK² (1)}

${ }^{1}$ Prof. Dr., Gebze Teknik Üniversitesi, Harita Mühendisliği Bölümü, Kocaeli, Türkiye

${ }^{2}$ Yük. Müh., T.C. Tarım ve Orman Bakanlığı, Çölleşme ve Erozyonla Mücadele Genel Müdürlüğü, Ankara, Türkiye

ORCID: A.Ç.A. 0000-0003-4912-9027; G.A. 0000-0003-4070-0223

\section{ÖZ}

Heyelanlar, ülkemizde önemli derecede can ve ekonomik kayba neden olmuş afet türü olduğundan heyelan duyarlılık haritalarının üretilmesi öncelikli araştırma konularındandır. Bu çalışmada, istatistik ve makine öğrenmesi teknikleri kullanılarak sığ heyelanlara ilişkin heyelan duyarlılık analizinin gerçekleştirilmesi ve Rize- Taşlıdere Havzası örneği ile modelin performansının değerlendirilmesi amaçlanmaktadır. Öncelikle konuya ilişkin literatür irdelenmiş, havzanın drenaj alanı içerisinde çalışma alanı genel özellikleri ve sığ heyelan envanterinin oluşturulmasına yönelik ayrıntılı araştırmalar yürütülmüştür. Heyelan duyarlııı haritasının üretilmesinde girdi parametresi olarak Coğrafi Bilgi Sistemleri (CBS) teknikleri ile üretilmiş onbeş parametre kullanılmıştır. Bu parametreler; arazi kullanımı, litoloji, yükselti, eğim, bakı, pürüzlülük, plan eğriselliği, profil eğriselliği, pürüzlülük indeksi, akarsu aşındırma gücü indeksi, topoğrafik nemlilik indeksi, sediman taşıma kapasitesi, drenaj yoğunluğu, drenaja olan mesafe, yol yoğunluğu ve yola olan mesafedir. Heyelan duyarlııı haritası için heyelan envanteri ve girdi parametreleri kullanılarak, Frekans Oranı (FO), Lojistik Regresyon (LR) ve Yapay Sinir Ağları (YSA) yöntemleri ile uygun parametre kestirimi ve analizler gerçekleştirilmiştir. Üretilen haritalar beş duyarlıık sınıfında belirlenmiş, performansının değerlendirilmesinde ROC (Bağıl İşlem Eğrisi) eğrisi altında kalan alan olan AUC (Eğri altındaki alan) değeri FO 0,72, LR 0.83, YSA 0.87 olarak elde edilmiştir. Böylelikle mevcut YSA tekniğinin daha yüksek doğrulukta sonuç vermesine rağmen, LR tekniğinin yakın doğrulukta ve kullanılabilir olduğu görülmektedir.

Anahtar kelimeler: Heyelan Duyarlılık, Yapay Sinir ağları, Lojistik Regresyon

\section{ABSTRACT}

As a disaster type, landslides cause significant life and economic losses; hence, producing landslide susceptibility maps is a priority research topic. This study aims to perform a landslide susceptibility analysis for shallow landslides by using statistics and machine learning techniques and evaluate the model performance using the Rize-Taşlıdere Basin as an example. First, literature was examined. Next, a detailed research was performed on the study area characteristics and the landslide inventory creation. Fifteen parameters (i.e., land use, lithology, elevation, slope, aspect, roughness, plan curvature, profile curvature, stream erosion index, topographic humidity index, sediment-carrying capacity, drainage density, distance to drainage, road density, and distance to road) produced by the geographic information system techniques were used as the input parameters in producing the landslide susceptibility map. Using the landslide inventory and input parameters, a parameter analysis was performed for the landslide susceptibility map in five classes by employing the frequency ratio (FR), logistic regression (LR), and artificial neural network (ANN) methods. The area under the curve and the area under the relative operating curve (AUC) were used to evaluate the model performance. The results show FR of $0.72, \mathrm{LR}$ of 0.83 , and ANN of 0.87 . Although the ANN technique provided results with a higher accuracy, the LR technique that was near accurate was usable.

Keywords: Landslide Susceptibility, Neural Networks, Logistic Regression

Başvuru/Submitted: 23.10.2020 • Revizyon Talebi/Revision Requested: 01.01.2021 • Son Revizyon/Last Revision Received: 07.03 .2021 • Kabul/Accepted: 25.10 .2021

Sorumlu yazar/Corresponding author: Gehver ALTÜRK / gehveralturk@gmail.com

Atıf/Citation: Aydinoglu, A. C., \& Alturk, G. (2021). Heyelan duyarlılık haritalarının istatistik ve makine öğrenmesi teknikleri kullanılarak Üretilmesi: Taşlıdere havzası örneği (Rize). Cografya Dergisi, 43, 159-176. https://doi.org/10.26650/JGEOG2021-814561 


\section{EXTENDED ABSTRACT}

Landslides are a disaster type that cause significant life and economic losses in our country. Hence, landslide susceptibility studies to reduce landslide damages and land use planning have become a very important issue for both scientists and public institutions. This study aims to perform a landslide susceptibility analysis for shallow landslides by using statistics and machine learning techniques and evaluate the model performance using the Rize-Taşlıdere Basin as an example. The basin representing the study area is considered as a potential landslide area due to its geographical features.

The literature on the subject was first examined. Next, a detailed research was performed on the general characteristics of the study area and the creation of a shallow landslide inventory within the drainage area of the basin. The inventory data of 878 landslides with point geometry were defined in the study area. Fifteen parameters produced by geographic information system techniques (i.e., land use, lithology, elevation, slope, aspect, roughness, plan curvature, profile curvature, roughness index, stream erosion index, topographic humidity index, sediment-carrying capacity, drainage density, distance to drainage, road density, and distance to road) were used as the input parameters in producing the landslide susceptibility map.

Using the landslide inventory and input parameters, appropriate parameter estimation and analysis were performed to the landslide susceptibility map by employing the frequency ratio (FR), logistic regression (LR), and artificial neural network (ANN) methods. FR is a widely used method because of its easy applicability. It is defined as the ratio of the probability of a disaster event to the probability of it not happening. The effects of the parameters causing landslide events are independently evaluated. According to the FR susceptibility map, $0.20 \%$ of the basin has very low landslide susceptibility (i.e., $11.47 \%$ low, $46.32 \%$ medium, 40.86\% high, and $1.15 \%$ very high).

LR is the expression of the probability values of the dependent variable defining the landslide inventory according to the independent variables defining the input parameters. It determines the cause-effect relationship between the dependent and independent variables when the dependent binary variable (yes-no) expresses the landslide inventory. Each class of geology and land use was independently added to the analysis from each other; thus, the number of independent variables was 26 . The LR susceptibility map showed that $4.55 \%$ of the basin has very low landslide susceptibility (i.e., 18.65\% low, 17.45\% medium, 43.37\% high, and 15.99\% very high landslide susceptibility).

The ANN is the computer model of this biological nervous system. Weights indicate the importance of the information in an artificial nerve cell and its effect on the cell. The inputs are multiplied by the weights of the connections they come from to adjust the effect of the inputs on the output to be produced. The weight values change to zero, negative, or positive. Positive and negative values indicate that the information has a positive or a negative effect. The inputs with zero weight are ineffective. In the ANN technique, the number of hidden layers is one. The number of neurons is selected, and the network structure is 26-18-1. The "momentum factor" is 0.5; the RMS is 0.001; the iteration number is 10.000; and the sigmoidal function acts as the activation function. The landslide susceptibility map is then obtained. The ANN susceptibility map showed that $6.52 \%$ of the basin has a very low landslide susceptibility (i.e., $7.20 \%$ low, $18.9 \%$ medium, $36.02 \%$ high, and $31.35 \%$ very high susceptible).

The area under the curve and the area under the relative operating curve were used to evaluate the performance. The AUC value was obtained as FO 0.72, LR 0.83, and ANN 0.87. Although the ANN gives a more accurate result than the other techniques, it is a complex analysis method. Creating a network design is a topic that should be studied in detail because the results will be optimistic in the case of excessive learning. The LR technique provided near-accurate results; hence, it is a more easily applicable method than the ANN. The weight coefficients of the parameters and their effect on the analysis are presented one by one. 


\section{GİRIŞ}

Yer yüzeyi bir yandan doğal afetler bir yandan da insan etkili faaliyetlerden ötürü sürekli değişimlere uğramaktadır. $\mathrm{Bu}$ değişimlere sebep olan etmenlerden olan kütle hareketlerinin meydana gelmesinde, arazinin jeolojisi, jeomorfolojik özelliği, eğimi, birbirinden farklı titreşimler, bitki örtüsü ve ayrışma gibi faktörler etkili olmaktadır (Özdemir, 2008). Kütle hareketi olan heyelan; yamacı oluşturan kaya, toprak veya benzeri malzemenin stabilitesinin bozulması neticesinde yer çekiminin etkisinde yamaç boyunca hareketlenerek dengeye ulaşana kadar şekil ve yer değiştirmesidir (Cruden, 1991). Başka bir ifadeyle heyelanlar, insan aktivitelerinin yanı sıra, arazi kullanımı, bitki örtüsü, şiddetli yağış ve sismik aktiviteler tarafindan tetiklenen bir kütle hareketidir (Soeters ve Van Western, 1996).

Varnes'ın (1978) heyelan sınıflandırmasına göre; düşme, devrilme, kayma, yanal yayılma ve akma duraylılık türleri tanımlanmaktadır. Malzeme türü olarak da heyelanlar toprak ve kaya zeminde meydana gelmektedir. Heyelanlar derinliklerine göre, sığ ve derin heyelanlar olarak ifade edilebilir (Frehner vd., 2007). Siğ heyelanlar, genellikle $1.5 \mathrm{~m}$ ve $5 \mathrm{~m}$ arasında kayma düzlemi derinliğinde, 0.5 ha'dan küçük kayma alanında ve $25^{\circ}$ üstündeki eğimli yamaçlarda gerçekleşirken; derin heyelanlar, genellikle $5 \mathrm{~m}$ 'den yüksek kayma düzlemi derinliğinde ve 0.5 ha'dan büyük kayma alanında gerçekleşir.

Heyelanların ekonomik ve can kaybına neden olmasıyla, heyelan zararlarının azaltılmasına ve arazi kullanım planlamalarına yönelik heyelan duyarlılık çalışmaları, hem bilim adamlarını hem de kamu kurumlarını ilgilendiren oldukça önemli bir konu haline gelmiştir. Heyelanların verdiği zararları önleyebilmek veya azaltabilmek için heyelan envanterinin tespiti ve duyarlılık analizi ile risk haritalarının oluşturulması gerekmektedir. Söz konusu tehlike nedeniyle tehdit edilen risk altındaki elemanlara ilişkin risk değerlendirmeleri yapılabilmektedir. Coğrafi Bilgi Sistemleri (CBS), bilişim teknolojileri ve yazılımlarındaki gelişmeler; çok sayıdaki verinin depolanmasına, istatistiksel analizlerle değerlendirilmesine, makine öğrenmesi ve yapay zekâ yöntemlerinin heyelan duyarlılık analizinde kullanımına olanak sağlamaktadır (Aleotti ve Chowdhury, 1999; Yüksel, 2007).

Heyelan duyarlılık haritası, meydana gelmiş heyelan olaylarını temsil eden envanter ile bu olaylara sebep olan temel faktörler belirlendikten sonra, çeşitli analizler neticesinde heyelan olma potansiyeline sahip alanların dağılımını ve olasılığını göstermektedir. Heyelan duyarlılık analizi için parametreleri temsil eden veri setlerinin üretilmesinde ve bir arada analizinde CBS teknolojileriyaygın olarak kullanılmaktadır. Heyelan duyarlılık haritasının üretilmesi için uluslararası literatürde Frekans Oranı (FO) gibi istatistik, Lojistik Regresyon (LR) ve Yapay Sinir Ağları (YSA) gibi makine öğrenmesi teknikleri yaygın olarak test edilmektedir. Bu kapsamda, Arca ve Kutoğlu (2017) Batı Karadeniz'de Kozlu bölgesinde FO tekniğini, Ercanoğlu ve Temiz (2011) Azdavay-Kastamonu'da ve Ayalew ve Yamagishi (2005) Kakuda-Yahiko Dağları'nda LR tekniğini değerlendirmiştir. Yılmaz (2009) Sivas Koyulhisar bölgesinde, Yeşilnacar ve Topal (2005) Hendek'te, Nefeslioğlu vd. (2008) İspir ve çevresinde, Eker vd. (2012) Bartın ili Ulus ilçesinde, Alkevli (2015) Karabük Yenice'de LR ve YSA yöntemlerini uygulamış ve performanslarını test etmiştir. Goméz ve Kavzoğlu (2005) Venezuela'nın Jabonosa Nehri Havzası'nda, Lee ve arkadaşları (2003) Kore Yongin Bölgesi'nde, Tekin vd. (2015) Doğu Akdeniz bölgesi içerisinde, Ercanoğlu (2005) Bartın'da, Yılmaz (2010) Giresun Şebinkarahisar'da, Can (2014) Karabük ili sınırları içerisinde, Çan ve Tekin (2016) Akdeniz bölgesinde, Tekin ve Çan (2019) Ermenek Çayı havzasında YSA ile model oluştururken heyelan duyarlılık alanlarının belirlenmesinde iyi sonuçlar verdiğini belirlemiştir.

Böylelikle istatistik ve makine öğrenmesi tekniklerinin kullanılarak parametrelerin irdelenmesi ve yüksek doğrulukta heyelan duyarlılık haritalarının üretilmesi için en uygun yaklaşımın belirlenmesine yönelik araştırma ihtiyacı ortaya çıkmıştır.

\section{AMAÇ VE YÖNTEM}

$\mathrm{Bu}$ çalışmada, sı̆̆ heyelanların meydana gelmesinde potansiyel riske sahip Taşlıdere Havzası (Rize) örneği ile heyelan duyarlılık haritalarının üretilmesi için örnek yaklaşımların belirlenmesi amaçlanmaktadır. Böylelikle makine öğrenmesi yöntemlerinden YSA ve LR ile istatiksel yöntemlerden FO yöntemleri ve literatür çalışması ile belirlenen parametreler uygulamada test edilmektedir. Çalışma dört aşamalı olarak gerçekleştirilmiştir (Altürk, 2019):

- Çalışma alanının incelenmesi ve heyelan envanterinin sağlanmas1,

- CBS analizleri ile heyelana etki eden faktörler için parametreleri temsil eden veri setlerinin hazırlanmas1,

- LR, FA ve YSA teknikleri kullanılarak heyelan duyarlılık haritalarının üretilmesi,

- Performans değerlendirilmesi kapsamında doğruluk analizlerinin yapılmasıdır. 
Çalışma kapsamında; CBS ile parametreleri temsil eden veri altlıklarının üretilmesinde ArcGIS 10.4, LR tekniğinin uygulamalarında IBM SPSS Statistics 20 ve YSA tekniğinin uygulamasinda IDRISI 17.0 The Selva Edition programları kullanılmıştır.

2.1. Çalış̧ma alanında parametreleri temsil eden veri setlerinin hazırlanması

Rize-Taşlıdere havzasının bulunduğu Güneysu ilçesi, Rize il merkezinin güneydoğusunda ve $107 \mathrm{~km}^{2}$ alana sahip olan Rize'nin iç kesim ilçelerindendir. Havzanın toplam alanı 33.092,11 ha'dır (Şekil 1). Meteorolojik ölçümlere göre (31 yıllık rasat) yıllık ortalama yağ yüksek sıcaklığ $18^{\circ} \mathrm{C}$ ve ortalama sıcaklığ 1 ise $14,1^{\circ} \mathrm{C}$ 'dir. Bu veriler kapsamında Erinç'in Yağış Müessiriyeti İndisine göre iklim ve vejetasyon tipi incelendiğinde (Erinç, 1965), Taşlıdere havzasının iklim tipinin çok nemli ve vejetasyon tipinin ise çok nemli mıntıka ormanları olduğu belirlenmiştir. Çalışma alanı içerisinde meydana gelen heyelanların frekans aralı̆̆ ve derinliği incelendiğinde ise daha çok sığ heyelanların meydana geldiği gözlenmiştir.
Uluslararası ve ulusal düzeyde yapılan literatür çalışması dikkate alınarak çalışma alanı için kullanılabilir veri altlıkları belirlenmiş̧ir. Heyelan duyarlılık haritasının üretilmesinde girdi parametresi olarak CBS teknikleri ile üretilmiş 15 parametre belirlenmiştir. Bu parametreler; arazi kullanımı, litoloji, yükselti, eğim, bak1, pürüzlülük, plan eğriselliği, profil eğriselliği, pürüzlülük indeksi, akarsu aşındırma gücü indeksi, topoğrafik nemlilik indeksi, LS faktörü, drenaj yoğunluğu, drenaja olan mesafe, yol yoğunluğu ve yola olan mesafedir. Heyelan envanteri, heyelan duyarlılığını etkileyen faktörler ve bu parametreleri temsil eden veri setlerinin kapsamı aşağıda özetlenmiştir.

Heyelan Envanteri: Heyelan envanter haritalar1; heyelan duyarlılık, tehlike ve risk haritalarının üretilebilmesi amacıyla kullanılan temel veri altlıklarıdır. Heyelan envanteri, bir alandaki heyelanların konumu, türü, aktivitesi ve fiziksel özelliklerine dair bilgileri içerir. Çölleşme ve Erozyonla Mücadele Genel Müdürlüğü'nün (ÇEMGM, 2016) çalışmaları kapsamında, sı̆̆ heyelanların envanteri (kayma yüzeyi derinliği < 5m) 1995 yılına ait 1:15.000 ölçeğinde renkli kızılötesi (infrared) stereo hava fotoğrafları ve 2014 yılına ait yüksek çözünürlüklü uydu

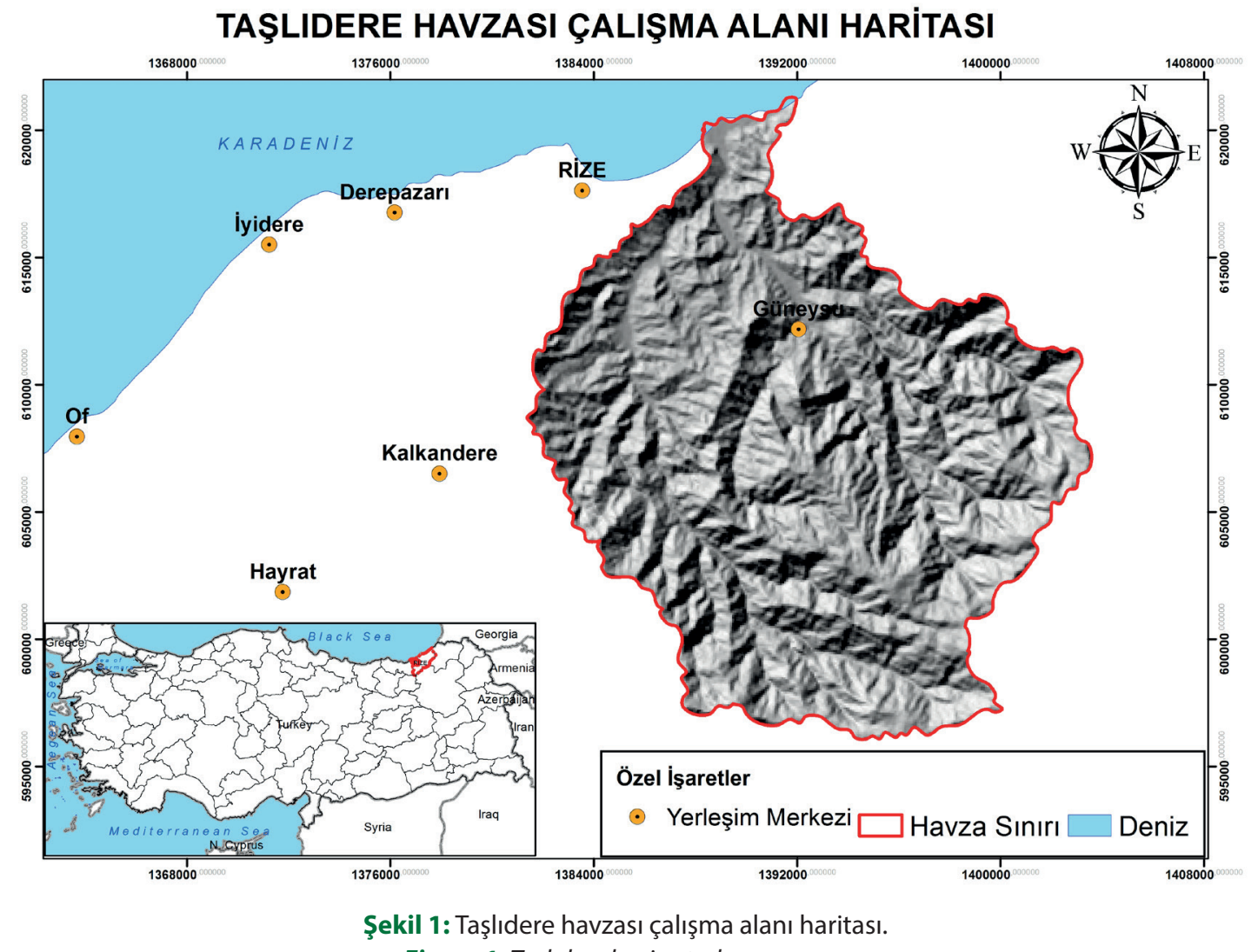

Figure 1: Taşlıdere basin study area map. 
görüntüleri yorumlarından oluşturulmuştur. Rize Güneysu ilçesi Taşlıdere havzasında 878 heyelanın envanter verisi nokta geometride tanımlanmıştır (Şekil 2a).

Jeolojik Özellikler: Çalışma sahasının genel jeolojisi Maden Tetkik Arama (MTA)'nın 1/100.000 ölçekli jeoloji paftalarından yararlanılarak oluşturulan genel jeoloji haritası yardımıyla belirlenmiştir (ÇEMGM, 2016). Çalışma alanı Güven (1998) tarafından Çatak formasyonu olarak adlandırılmış bazik karakterli volkanoklastik birim ile başlamaktadır. Çatak formasyonuna uyumlu olarak üzerine gelen asidik karakterli lav ve piroklastlar tarafindan Kızılkaya formasyonu olarak tanımlanmaktadır. Asidik volkanitleri bazik karakterli volkanit, volkanoklastik ve çökel kaya ardalanmasından oluşan volkanotortul istif Çağlayan formasyonu üzerler. Üst Kretase yaşlı birimlerin içerisine ilerleyen; granitten gabroya dek geniş olan yelpazede değişen intrüzif kompleks intrüzyon yaşı gözetilmeksizin Kaçkar granitoyidleri olarak tanımlanmaktadır.
TAŞLIDERE HAVZASI HEYELAN ENVANTER HARITASI
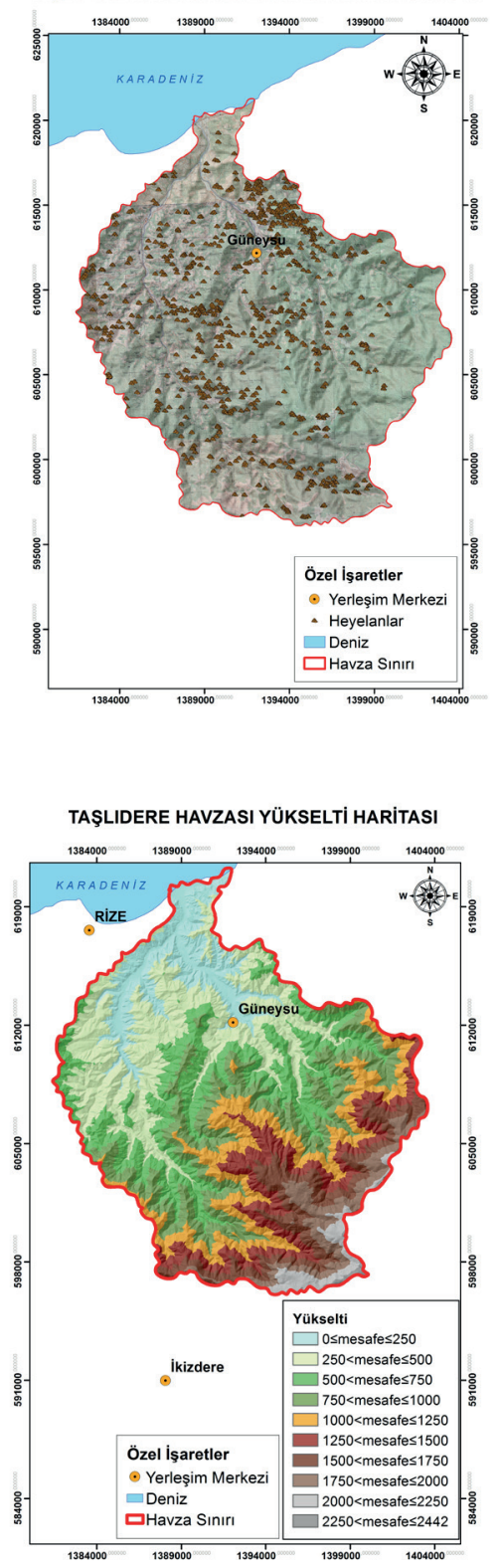
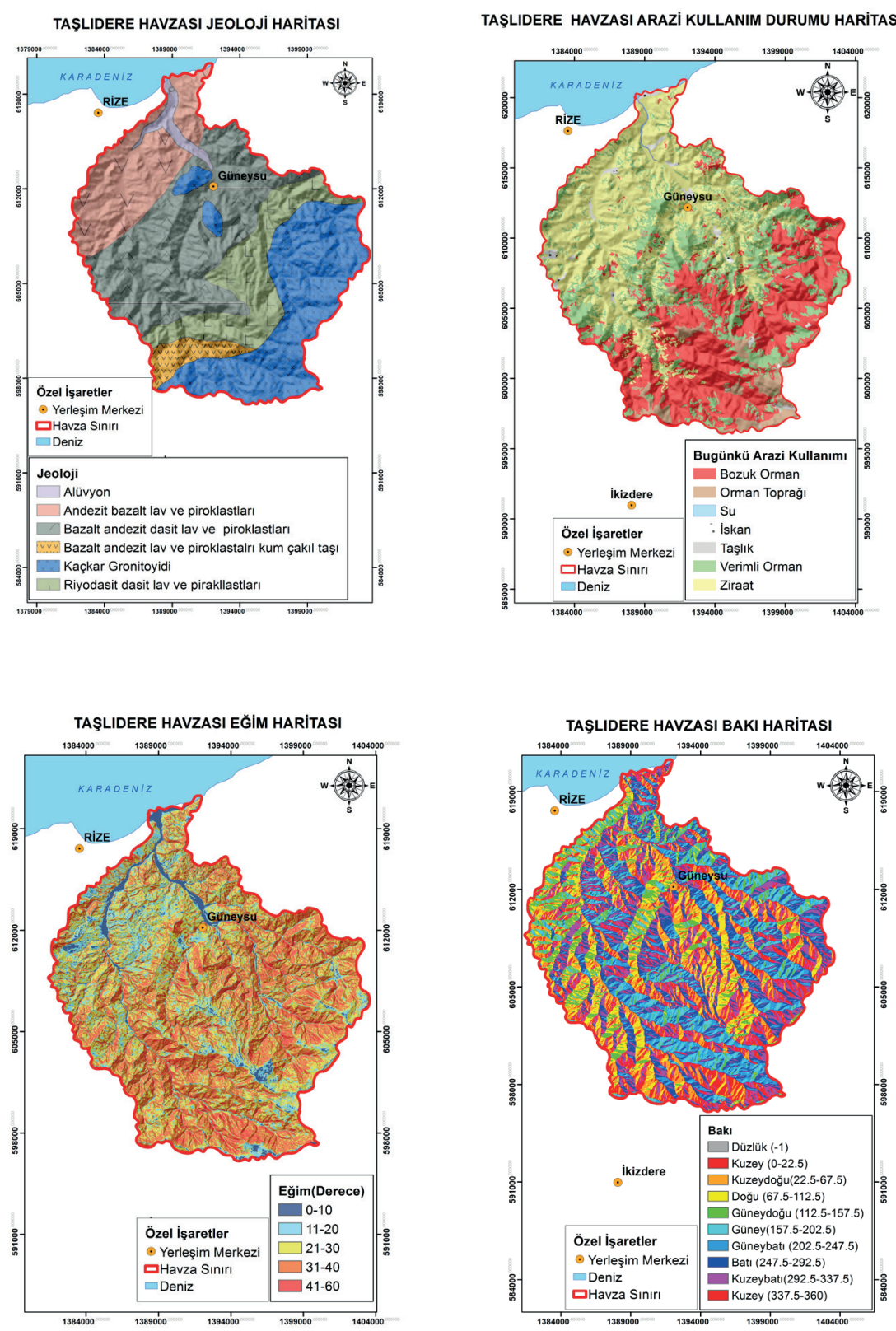

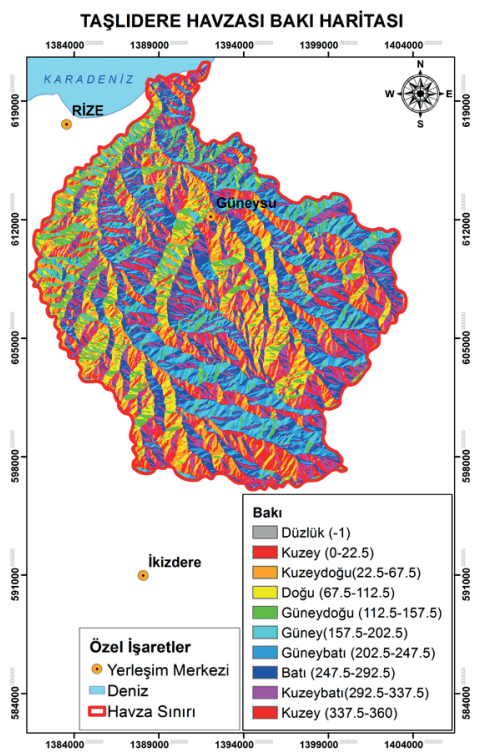

Şekil 2. (a) Heyelan Envanteri (ÇEMGM, 2016), (b) Jeoloji (ÇEMGM, 2016), (c) Arazi Kullanım (OGM, 2007), (d) Yükselti, (e) Eğim ve (f) Bakı parametresi haritaları.

Figure 2. (a) Landslide Inventory, (b) Geology, (c) Land Use, (d) Elevation, (e) Slope and (f) Aspect parameter maps. 
Üst Kretase yaşlı birimler üstünde taban konglomerası ile açısal uyumsuz durumdaki, çoğunlukla kırıntılı çökellerle başlayan ve üst kesimlerinde volkano-tortul seviyeleri barındıran diğer bir formasyon da Kabaköy formasyonu olarak tanımlanmaktadır. Formasyonun, kumtaşı, kumlu kireçtaşı ve marn ara tabakalarını içerdiği masif veya kalın tabakalı bol ojit ve hornblendli andezit-bazalt lav ve piroklastları tarafindan oluşturulan volkano-tortul bir istiften meydana geldiği belirtilmektedir (Yılmaz vd., 1998; Okay ve Şahintürk, 1997; Şaroğlu ve Yılmaz, 1986; Güven, 1998; Gedikoğlu vd., 1979; Özsayar vd., 1981; ÇEMGM, 2016-2) (Şekil 2b).

Arazi Kullanımı: Orman Genel Müdürlüğü tarafından üretilen amenajman haritaları temel altlık olarak kullanılmıştır (OGM, 2007). Havza \%0,11 su, \%0,17 taşl1k, \%1,4 yerleşim, $\% 4,2$ orman toprağ1, \%25,07 verimli orman, \%32,08 bozuk orman ve $\% 36,96$ 's ziraat olarak sınıflandırılarak bugünkü arazi kullanım durumu haritası çıkarılmıştır (Şekil 2c).

Yükselti: HGK tarafindan üretilmiş 10x10 çözünürlükteki SYM verileri kullanılmıştır. Havzanın yükselti değerleri minimum 0 m, maksimum $2442 \mathrm{~m}$ olup ortalama yükselti 845 m'dir (ÇEMGM, 2016) (Şekil 2d).

Eğim: Heyelan duyarlılık haritalarının üretilmesinde kullanılan en önemli faktörlerdendir (Gomez ve Kavzoğlu, 2005; Ercanoglu, 2011; Nefeslioğlu vd., 2008; Ayalew vd., 2004; Yeon ve Ryu, 2010). Eğim, su ve diğer malzemenin graviteye bağlı hareketine etki etmektedir. Yüzeysel akışa bağlı topraktaki suyun miktarı, erozyon meydana getirme potansiyeli, toprak oluşumu vb. süreçlerle hidrolojik ve jeolojik yönden heyelanların meydana gelmesinde önemli bir faktördür (Wilson ve Gallant, 2000). Eğimin $0-10^{\circ}$ arasında düşük eğimli kısımlarında genellikle depolanma, $10^{\circ}$ ile $30^{\circ}$ arasındaki orta eğimli alanlarda kısmı derin oyuntular ve heyelanlar, $30^{\circ}$ nin üstündeki dik eğimli kısımlardaysa şiddetli erozyon, heyelan ve kaya düşmeleri görülmektedir (Milewski vd., 2009). Çalışma alanının eğim haritası SYM'den türetilmiş̧ir (Şekil 2e).

Bakı: Heyelan duyarlılık haritalamasında kullanılan faktörlerden biri olan bakı, topoğrafının güneşe olan açısını belirtir (Gökçeoğlu ve Ercanoğlu, 2001). Bakı haritası, SYM'den türetilmiş olup yamaçların hangi yöne eğimli olduğu kuzeyi $0^{\circ}$ alarak saatin dönüş yönüne göre derecelendirir. Çalışma alanının yaklaşık \%46'sının kuzey, \%30'unun güney, \%14'ünün bat1 ve \%10'unun doğu bakıya sahip olduğu gözlenmiştir (Şekil 2f).
Eğrisellik: Eğrisellik kavramı, arazi yüzeyinin herhangi bir düzlem tarafından kesişmesi sonucu oluşan doğrunun eğrilik değerini ifade etmektedir. Yamaç eğriselliği doğrultusuna bağlı olarak, bir yamaca ilişkin profil ve plan olmak üzere iki ayrı eğrisellik değeri elde edilmektedir. Profil yamaç eğriselliği, yamaç aşağı doğru yamaç eğimindeki değişim olarak açıklarken; plan yamaç eğriselliğini, belli bir topoğrafik yükseklik boyunca yamaç yönelimindeki değişim olarak ifade etmektedir. Profil eğrisellik haritasındaki pozitif değerler konkav yamaçları, negatif değerler konveks yamaçları belirtir. Plan eğrisellik pozitif değerler konveks yamaçları, negatif değerler ise konkav yamaçları belirtir (Wilson ve Gallant, 2000). Çalışma alanının plan ve profil eğrisellik haritası SYM'den türetilmiştir (Şekil 3a).

Pürüzlülük İndeksi: Arazinin yüzey yapısı ve özelliklerinden biri olan pürüzlülük indeksi, 3 × $3 \mathrm{~m}$ boyutlara sahip raster pencere içerisinde her bir piksele ait yükseklik değerinin hesaplama yapılan pencere içindeki minimum yükseklikten çıkarılması ve maksimum ve minimum yükseklik aralığına oranı şeklinde hesaplanmaktadır (Evans, 1972). Buna göre havzanın $\% 2,86$ si düşük, $\% 34,67$ si orta ve $\% 62,47$ si yüksek pürüzlülük sınıfında yer almıştır (Şekil 3b).

Topoğrafik Nemlilik İndeksi (TWI): Topografyanın hidrolojik süreçler üzerindeki etkisini, toprak nemi ve yüzey doyumu konumsal dağılımının modellenmesi ve nicel olarak hesaplanması için tasarlanmıştır. İlk kez Beven ve Kirkby (1979) tarafindan ortaya atılan yaklaşım Barling (1992) tarafından aşağıdaki eşitlikle ifade edilmiştir. Topografik nemlilik indeksinin hesaplanmasında, akış yönünde türetilen akış toplama alanı bilgisi ile yamaç eğimi bilgisi kullanılır. Burada As özgül havza alanıdır $\left(\mathrm{m}^{2} \mathrm{~m}^{-1}\right)$ ve $\beta$ ise eğimdir. TNI değerleri SYM den türetilmiştir (Şekil 3c).

$$
T \mathrm{WI}=\ln \left(\frac{\mathrm{As}}{\tan \beta}\right)
$$

Akarsu Aşıındırma Gücü İndeksi (SPI): Akan suyun erozyon gücünü akarsu aşındırma gücü indeksi olarak tanımlamaktadır (Moore vd., 1991). Çalışma alanının akarsu SPI'si SYM'den aşağıdaki eşitlik ile türetilmiştir (Şekil 3d).

$$
S P I=A s \times \tan \beta
$$

Sediman Taşıma Kapasitesi - LS Faktör: Wilson ve Gallant (2000) yamaç uzunluğunun 100 m'den daha kısa ve yamaç eğiminin $14^{\circ}$ 'den küçük olduğu koşullar altında revize edilmiş toprak kaybı denklemi içerisindeki yamaç uzunluğu faktörüne denk olduğunu ifade etmektedir. Moore ve Burch (1986) sediman 
taşıma kapasite endeksinin (LS) hesaplanmasına yönelik aşağıdaki eşitliği önermiştir. $m$ ve $n$ değerleri ise sırasıyla 0,4 ve 1,3 olarak verilmektedir (Moore ve Wilson, 1992) (Şekil 3e).

$$
L S=(m+1)\left(\frac{A s}{22,13}\right)^{m}\left(\frac{\sin \beta}{0,896}\right)^{n}
$$

Drenaj Analizi: Yamaçlarda bulunan malzemenin doygunluk derecesi yamaç stabilitesini etkileyen önemli bir faktördür. Akarsular, yamacı ya da şevi topuktan aşındırarak, yamacı oluşturan malzemeyi akarsu seviyesine dek suya doyurarak ya da her iki şekilde de tetikleyerek yamaç stabilitesini olumsuz etkilemektedir (Saha vd., 2002; Yalçın, 2008). Analizler için öncelikle drenaj ağı, Strahler yöntemi ile SYM' den türetilmiştir.

Drenaj Yoğunluğu: Havzaların akarsularca yarılma oranını ifade eden drenaj yoğunluğu, havzanın akarsularca bölünmesini ve havzadaki su ile sediment üretimini etkileyen önemli bir etmendir. Horton (1945) drenaj yoğunluğunu $(D d)$ aşağıdaki eşitlikte belirtmiştir. Dd drenaj yoğunluğunu, $\sum \boldsymbol{L}$ toplam drenaj uzunluğunu $(\mathrm{km})$ ve A havza alanını $\left(\mathrm{km}^{2}\right)$ belirtmektedir (Şekil 4a).
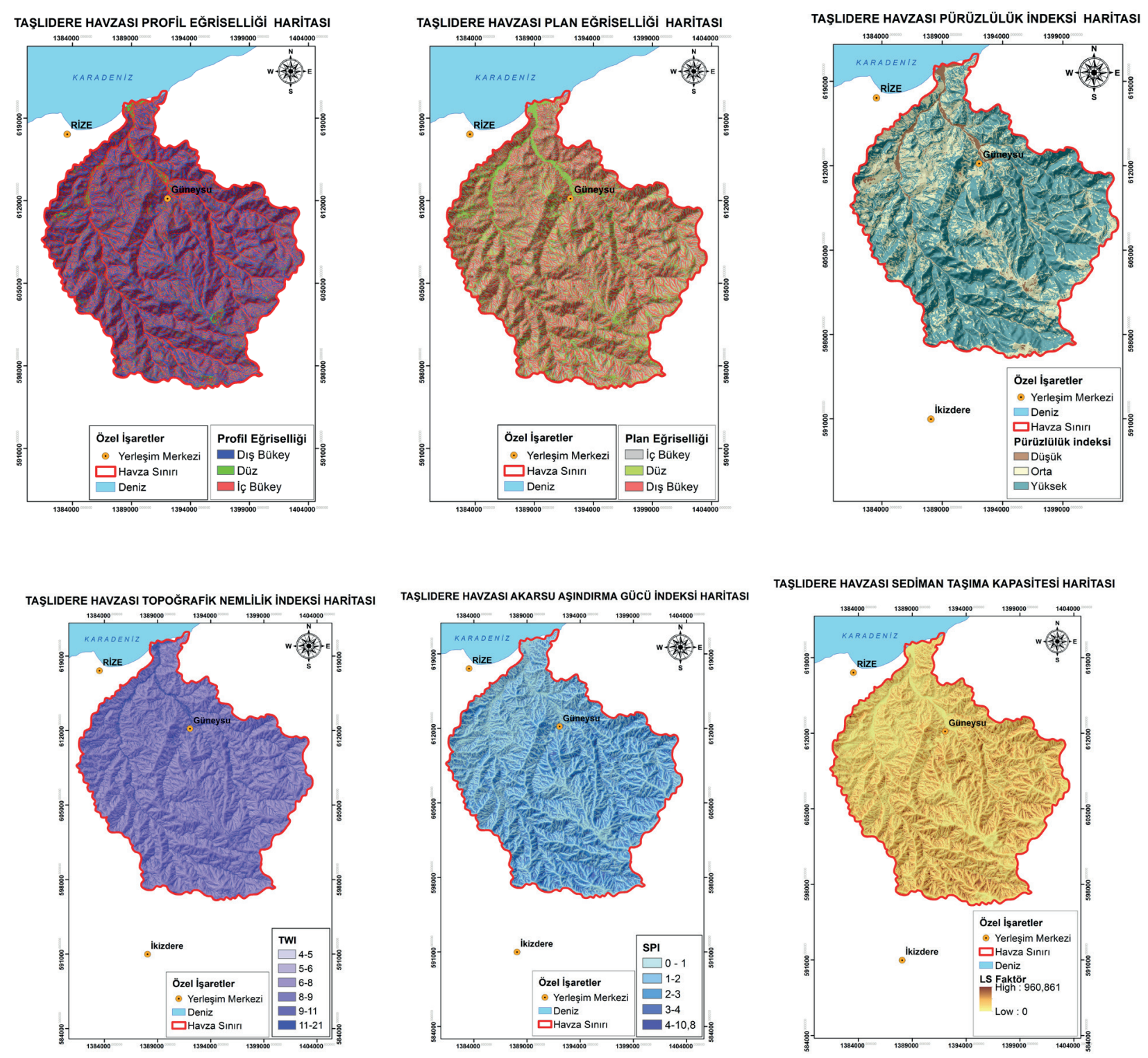

Şekil 3: (a) Eğrisellik, (b) Pürüzlülük, (c) Topoğrafik Nemlilik İndeksi, (d) Aşındırma Gücü İndeksi ve (e) Sediman Taşıma Kapasitesi parametre haritaları.

Figure 3: (a) Curvature, (b) Roughness, (c) Humidity, (d) Abrasion Force and (e) Sediment Transport parameter maps. 


$$
D_{d}=\frac{\sum L}{A}
$$

Drenaja Olan Mesafe: Yamaçların drenaja olan mesafesi stabilite açısından önemli diğer bir faktördür. Çalışma alanında drenaj alanına olan mesafe maksimum 807,31 m, minimum 0 ve ortalama ise 132,21 m olup standart sapma 102,61 m'dir (Şekil $4 b)$.

Yol Analizi: Yollar yamaçtaki hassas alanlarda topuk desteğinin yok olmasina sebep olduğundan veya yamaca ekstra
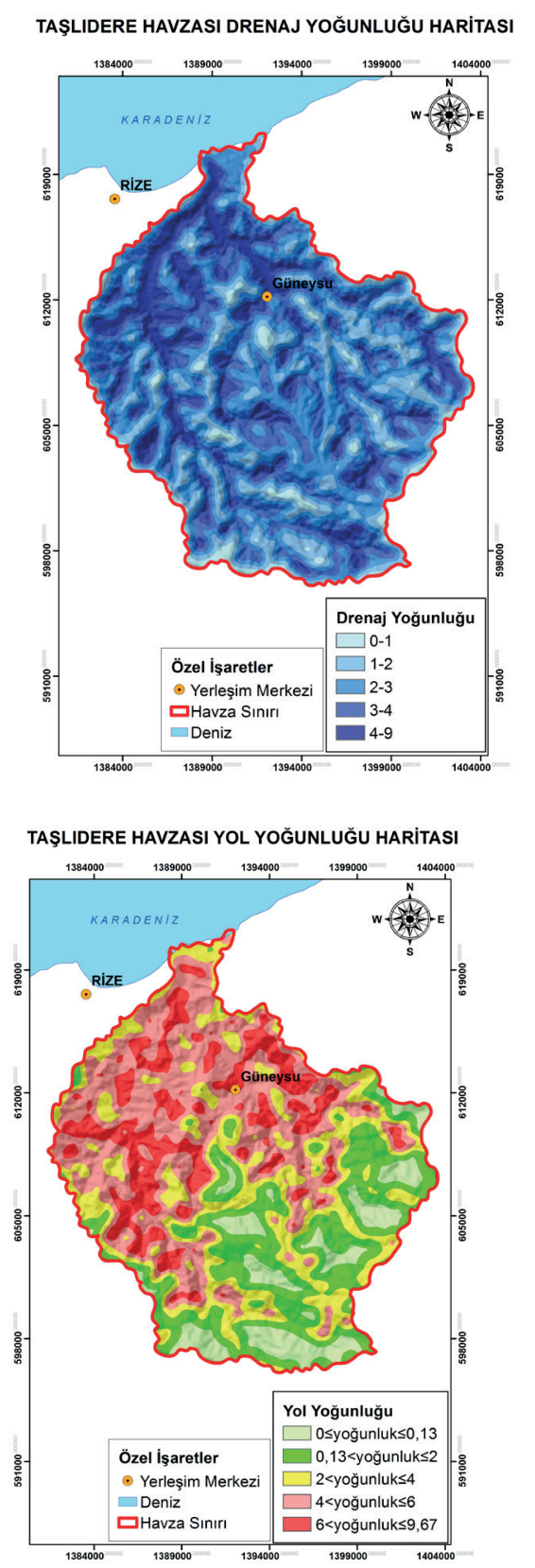

yük getirebildiğinden heyelan üzerinde etkili bir faktördür (Uzunsoy ve Görcelioğlu, 1985). Bu kapsamda heyelan duyarlılık analizinde yol yoğunluğu ve yola yakınlık analizleri gerçekleştirilmiştir. Havzanın yol ağı OGM İnşaat ve İkmal Dairesi Başkanlığından temin edilmiştir.

Yol Yoğunluğu: Yamaç sürekliliğini kestiğinden dolayı yollar, yüzeyin altındaki suların yüzeye çıkmasına sebep olmaktadır ve sular yol drenaj sistemlerince toplanmaktadır. Ancak şiddetli yağışlar sonrasında yetersiz ya da yanlış projelendirilmiş su drenaj tesisleri, yağış sularıyla beraber yüzey

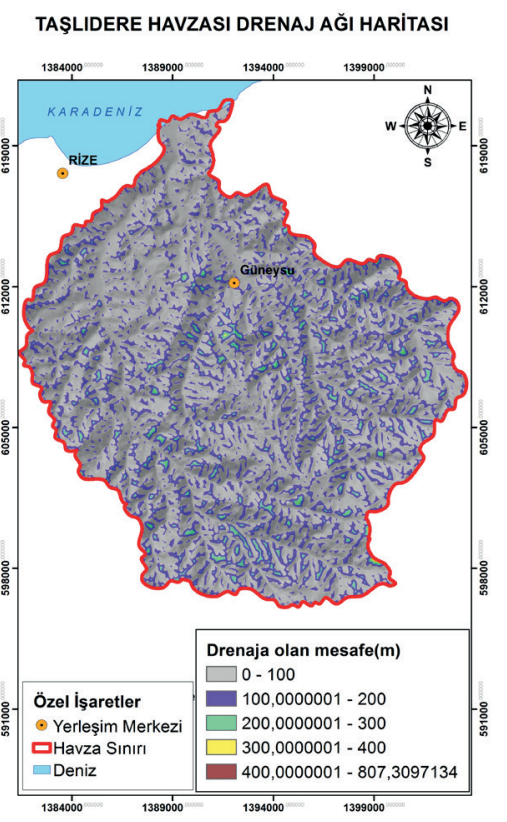

TAŞLIDERE HAVZASI YOLA OLAN MESAFE HARITASI

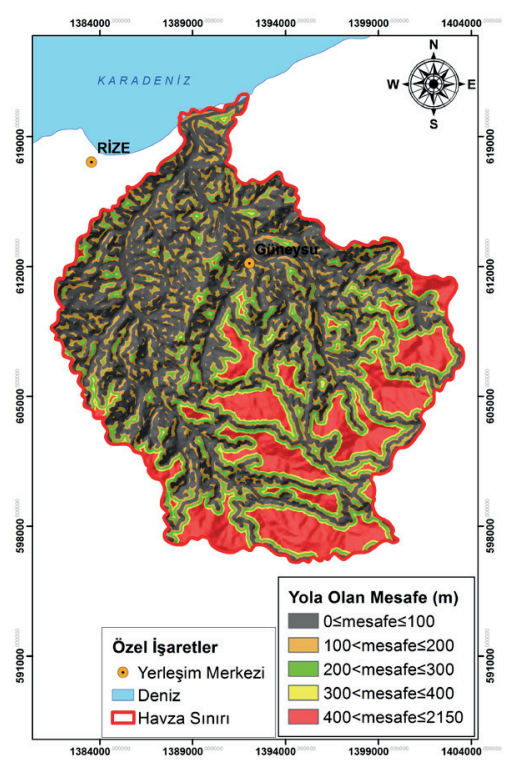

Şekil 4: $(a, b)$ Drenaj ve $(c, d)$ Yol parametre haritaları.

Figure 4: $(a, b)$ Drainage and $(c, d)$ Road parameter maps. 
altı sularını da tahliye edemediğinden dolayı heyelan oluşumunu tetiklemektedir (Furniss ve Yee, 1991). Çalışma alanında yol yoğunluğu değerleri $\left(\mathrm{km}^{-1}\right)$, minimum 0 , maksimum 9,67, ortalama 3,53 olarak hesaplanmıştır (Şekil 4c).

Yola Olan Mesafe: Yollar, yapım aşamasında yamaç dengesini bozduğundan dolayı heyelan görülmeyen alanlarda dahi heyelan oluşumunu tetiklemektedir (Harr ve Nichols, 1993; Larsen ve Parks, 1997). Bundan dolayı yollar heyelan duyarlılık analizine dâhil edilmektedir. Havzanın yola olan mesafesi minimum $0 \mathrm{~m}$, maksimum $2150 \mathrm{~m}$, ortalama $205,17 \mathrm{~m}$ ve standart sapma değeri 266,830 m olarak hesaplanmıştır (Şekil 4d).

\subsection{Analiz Teknikleri}

\subsubsection{Frekans Oranı Yöntemi (FO)}

Çalışma alanına özgü fiziksel koşulların ve heyelanları tetikleme süreçlerinin anlaşılması, heyelanların olma olasıllğını değerlendirmek için büyük önem taşımaktadır. Frekans oranı, CBS teknikleri ve coğrafi veriler kullanılarak heyelan duyarlılığ değerlendirmesi için nicel bir tekniktir. Heyelan duyarlıllı̆ haritalaması için heyelanların coğrafi dağılımının heyelana sebep olan faktörlerden etkilendiğini ve gelecekteki heyelanların da geçmiş heyelanlarla aynı koşullar altında gerçekleşeceğini varsaymak önemlidir (Lee ve Talib, 2005).

Frekans oran1, kolay uygulanabilir olmas1 sebebiyle yaygin biçimde kullanılan bir yöntemdir. Herhangi bir olayın olma olasılığının olmama olasılığına oranı frekans oranı şeklinde tanımlanmaktadır (Bonham-Carter, 1994). Temelde koşullu bağımsızlık varsayımı kabul edilmektedir. Heyelanların gelişmesine neden olan parametrelerin heyelan oluşumundaki etkisi birbirinden bağımsız olarak değerlendirilmektedir.

Çalışma esnasında FO'nun uygulanması, iki değişkenli istatiksel yöntem temelinde gerçekleştirilmiştir. Bunun için öncelikle mevcut heyelanlı alanlarla heyelana sebebiyet veren faktörler arasında ilişki kurularak heyelan yoğunluğu irdelenmiştir. Parametreler için haritalama ünitesi olarak 10x10 $\mathrm{m}^{2}$ mekânsal çözünürlüğe sahip grid hücreler tercih edilmiştir.

$$
\begin{aligned}
& F O=\frac{b}{a} \\
& H D \dot{\mathrm{I}}=F O_{1}+F O_{2}+\cdots+F O_{n}
\end{aligned}
$$

" $a$ " heyelanı tetikleyen parametrenin her bir alt sınıfindaki heyelan varlığının yüzdesi, " $b$ " ise heyelanı etkileyen parametrenin her bir sınıfının kendi içindeki yüzdesini ifade etmektedir. Frekans tablosundaki değerler hesaplanırken her sınıfa düşen toplam piksel sayıları (A) ile bu sınıflara düşen heyelanlı piksel sayıları (B) karşılaştırılmıştır. Bu karşılaştırma sonucunda parametre alt sınıfının piksel sayısının, alandaki toplam piksel sayısına oranı " $a$ " ile parametre alt grubundaki heyelanlı piksel sayısının toplam heyelanlı piksel sayısına oranı " $b$ " hesaplanmıștır. Yüzdelik değerler bulunurken her bir sınıftaki piksel sayıları toplam sayıya bölünüp 100 ile çarpılarak elde edilmiştir. Böylece her bir parametreye ait sınıfların frekans oranı (b/a) belirlenmiştir. FO değerlerinin normalleştirilmesi için parametre alt grubundaki tüm FO değerleri, en büyük FO değerine bölünüp 100 ile çarpılmış ve normalleştirilmiş frekans oranları NFO değerleri elde edilmiştir.

\subsubsection{Lojistik Regresyon Yöntemi (LR)}

Lojistik regresyon, bağımlı ikili değişken (var-yok, evethayır) olduğunda, bağımlı değişkenlerle bağımsız değişkenler arasındaki sebep sonuç ilişkisini belirleyen, bağımsız değişkene göre bağımlı değişkenin olması muhtemel değerlerinin olasılık şeklinde ifade edilmesidir (Hosmer vd., 2013). LR yönteminde bağımsız değişken verileri kategorik ya da süreklidir. LR, bu bağımsız değişkenlerin doğru ifade edilebilmesinde sağladığı avantajdan dolayı istatistiksel analizlerde oldukça s1k tercih edilmektedir. LR değerlendirmesinde elde edilen olasılık fonksiyonu aşağıdaki eşitlikte belirtilmiştir.

$$
P(Y=1)=p_{i}=\frac{1}{1+e^{-\left(\beta_{0}+\beta_{1} X_{1}+\beta_{2} X_{2}+\ldots+\beta_{n} X_{n}\right)}}
$$

LR analizinde bağımlı değişken kesikli olup [0-1] aralığındadır. Eşitliğin sağında olan ve bağımlı değişkenle bağımsız değişkenlerin korelasyonunu veren değer $-\infty$ ile $+\infty$ arasında değişim göstermektedir. Elde edilen $-\infty$ ile $+\infty$ eğrisini doğrusal duruma döndürmek için lojit dönüşüm yapılmaktadır. $\mathrm{Bu}$ dönüşümde temel olarak P olasılık değeri 0'a yaklaştığında $-\infty, 1$ 'e yaklaştığında ise $+\infty$ 'a yaklaşmaktadır.

$$
L R=\log \left[\frac{P_{i}}{1-P_{i}}\right]=z_{i}=\beta_{0}+\beta_{1} X_{1}+\beta_{2} X_{2}+\ldots+\beta_{n} X_{n}
$$

$L R$ lojistik regresyon denklemi, $X$ ise heyelana etkiyen parametreler olarak öngörülen bağımsız değişkenleri ve $\beta$ ise bağımsız değişkenlerin regresyondaki katsayıları olarak ifade edilmektedir (ÇEMGM, 2016-2; Çan ve Tekin, 2016). Jeoloji ve arazi kullanımının herbir sınıfı analize birbirinden bağımsız 
eklendiğinden, bağımsız değişken sayısı mevcut diğer 14 parametre ile birlikte toplam 26 olarak belirlenmiştir. Lojistik regresyon analizlerine ilişkin uygulama sürecinde ilk aşamayı veri matrisinin hazırlanması oluşturmaktadır. Veri matrisi içerisinde her bir satır haritalama birimine karşılık gelen bir olayı tanımlarken, kolonlar bağımlı ve bağımsız değişkenleri tanımlamaktadır. Havzanın koordinatlı nokta bulutu verisi heyelan envanteri ile birleştirilerek tüm havzanın 10x10'lik nokta verisi elde edilmiş ve veri matrisinde heyelanlı piksellere 1 ve heyelansız piksellere de 0 değeri atanmıştır. Elde edilen bu veri setindeki her bir noktaya denk gelen tüm parametre değerleri atanarak bağımsız değişkenler ile bağımlı değişkenlerin veri matrisi hazırlanmıştır. Analizin yapılabilmesi için veri matrisindeki heyelanlı ve heyelansız noktaların \%70'i eğitim ve \%30' u doğrulamada kullanılmak üzere rasgele örneklem yoluyla seçilmiştir.

\subsubsection{Yapay Sinir Ağları Yöntemi (YSA)}

İnsan sinir sistemi, nöron denilen tek hücreli küçük yapılardan oluşur. Nöron; dendrit, dendronitler, hücre gövdesi, sinaps ve akson olarak ifade edilen beş ana bileşenden oluşur. Dendritler, diğer nöronlardan gelen sinyalleri alır, dendronlar aracılığı ile sinyaller hücre gövdesine taşınır ve burada gelen sinyalin gücüne bağlı olarak kompozit sinyaller üretilir ve akson boyunca sinapslara iletilir. Yapay sinir ağı bu biyolojik sinir sisteminin bilgisayar ortamındaki modelidir (Konar, 2005). Bir yapay nöron, iki modül ile matematiksel olarak temsil edilir; (i) lineer aktivasyon ve (ii) sonlu bir bantta sinyal seviyelerini sınırlayan bir doğrusalsızlıktır. Burada toplama fonksiyonu bir hücre gövdesi olarak çalışır ve girdiler dendritler gibi davranır. Sinapslar doğrusal olmayan bir fonksiyonu modeller ve ağdan doğrusal olmayan birime olan ilişki akson gibi çalışır. Burada Net $x_{1}, x_{2}, \ldots, x_{\mathrm{n}}$ şeklinde tanımlanan girdilerin doğrusal bir toplamıdır.

$$
\sum_{i=1}^{n}=w i x i
$$

Ağırlıklar bir yapay sinir hücresindeki bilginin önem derecesi ile hücredeki etkisini belirtir. Girdilerin üretilecek çıktıdaki etkisini belirleyebilmek için girdiler, geldikleri bağlantıların $w_{1}$, $w_{2}, \ldots, w_{\mathrm{n}}$ ile belirlenen ağırlıkları ile çarpılır. Ağırlık değerleri sıfır, negatif veya pozitif olarak değişmektedir. "+” ve "-_" değerler bilginin pozitif veya negatif bir etkisi olduğunu gösterirken, ağırlığı sıfır olan girdiler etkisizdir.

Toplama fonksiyonundan çıkan toplam, seçilmiş bir aktivasyon fonksiyonuyla işlenerek bir çıktıya $y$ dönüştürülür (Web3, 2018). Şekil 5'de ifade edildiği gibi toplam, bazı eşik değerleri ile karşılaştırılır ve istenilen değerlere göre sınırlandırılır. Eğer toplam eşik değerinden büyükse işlem elemanı sinyal üretmektedir, aksi durumda işlem elemanı sinyal üretmemektedir. Söz konusu iki durum da ağ için önemlidir. Aktivasyon fonksiyonu çoğunlukla doğrusal olmayan ve kolay türevlenebilir bir fonksiyon şeklinde seçilir. En az ve en çok değerleri asimptotlarda birbirine yaklaştıran " $S$ " eğrisi, genellikle tercih edilen fonksiyondur. Dikkate alınan aralıklar 0 ve 1 arasında ise Sigmoid, -1 ile 1arasında ise Hiperbolik Tanjant fonksiyonu ile seçilmelidir (Can, 2014).

YSA analizinde kullanılacak parametreler için haritalama ünitesi olarak 10x10 $\mathrm{m}^{2}$ konumsal çözünürlüklü grid hücre verisi kullanılmıştır. Yapay sinir ağları tasarım aşamasında; eğitim, test ve doğrulama veri setleri oranları, gizli katmandaki nöron sayısı, aktivasyon fonksiyonu, momentum katsayısı, öğrenme katsayısı, iterasyon sayısı ve MSE (The Mean Square Error) değerlerinin belirlenmesi gerekmektedir.

Modelin geliştirilmesinde yararlanılacak eğitim setinin söz konusu problemi çözmede ihtiyaç olan yeter sayıda veri içermesi beklenir. Bir başka ifadeyle, YSA modelinin oluşturulmasında koşturulacak eğitim setinin özellikle kütle hareketine ilişkin duyarlılı̆̆ın kestirimi için yeter sayıda heyelan var ve heyelan yok bilgisine sahip olması gerekir. Nokta geometrideki 878 adet heyelanın \%70'i eğitim ve test, \%30'u doğrulama veri seti olarak ayrılmıştır. Daha sonra heyelan olmayan noktalardan da heyelanlı nokta sayısı kadar nokta seçilerek \%70'i eğitim ve test, \%30’u doğrulama veri seti olarak ayrılmıştır. Daha sonra seçilen noktaların veri setleri birleştirilerek veri matrisindeki heyelanlı olan noktalar "1" ve heyelan olmayan noktalar " 2 " olarak atanmıştır.

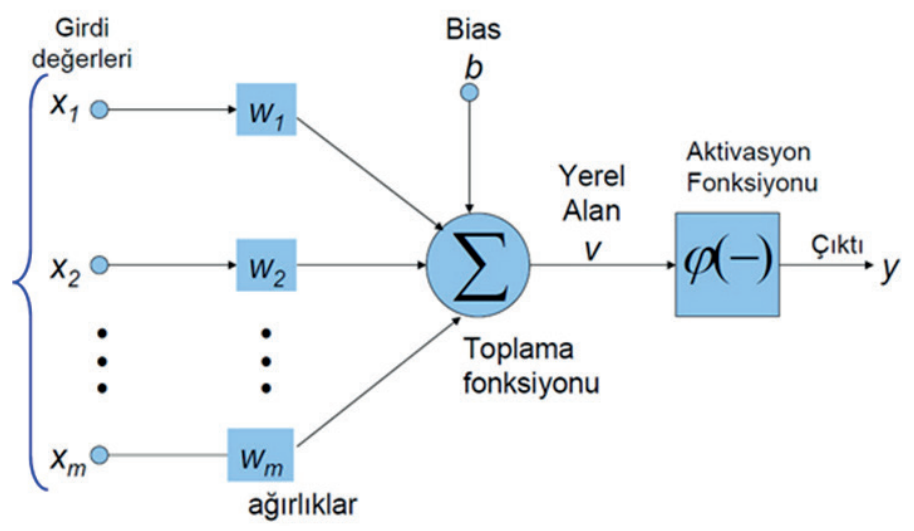

Şekil 5: Yapay bir nöron yapısı (Web3, 2018). Figure 5: An artificial neuron structure (Web3, 2018).

Gizli tabaka ve nöron sayılarının tespiti, YSA model analizlerinde önemli bir konudur. Hect-Nielsen (1990) yaklaşımı dikkate alınarak YSA modeli için gizli tabaka sayısı 1 olarak 
alınmıştır. Basher ve Hajmeer (2000) gizli katman içerisinde nöron sayısının çok az sayıda olması halinde karmaşık problemlerin çözülmesinde yetersiz olacağını ayrıca çok fazla sayıda nöron olması durumundaysa aşırı öğrenme sürecinin başlayacağı ve aşırı öğrenmenden dolayı sonuçtaki modelin genelleştirme yeterliliğini kaybedeceğini belirtmişlerdir. Çünkü analiz sürecinde eğitim setinin iterasyon süresi artan nöron sayısına bağlı üstel artmaktadır. Nöron sayısının hesaplanmasında Kaastra ve Boyd (1996) nöron sayısının parametre ve çıktı sayısının çarpımının karekökü olarak alırken, Wang (1994) nöron sayısını parametre sayısının üçte ikisi olarak alır (Nefeslioğlu vd., 2008). Bu bağlamda nöron sayısı 15 parametre içindeki jeoloji ve arazi kullanım sınıfları analize birbirinden bağımsız sokulduğundan, bağımsız değişken sayısı 26 olarak alınmış ve nöron sayısı bunun üçte ikisi olacak şekilde seçilerek ağ yapısı 26-18-1 olarak belirlenmiştir.

Öğrenme sürecini hızlandıran ve daha kararlı olmasını sağlayan öğrenme ve momentum katsayılarıdır. Öğrenme katsayısı, ağırlıkların değişim miktarına etki eder, katsayının çok küçük olması halinde aşırı öğrenme gerçekleşebilir ve öğrenme süreci uzayabilirken büyük bir değerdeyse yetersiz öğrenmeye sebep olur. Momentum katsayısı ise geri yayılımlı ağlarda öğrenme katsayısını arttırır ve öğrenme sürecini hızlandırır
(Jacobs, 1998). Wythoff (1993) momentum ( $\beta$ ) kat sayılarının 0,4 ile 0,9 arasında bir değer alabileceğini ifade etmiştir. Öğrenme ve momentum katsayısı bu aralık içerisinden 0,5 olarak seçilmiştir.

YSA analiz sürecinde veri setleri için yakınsama ölçütü olan RMSE (Root Mean Square Error) değerleri kullanılmıştır. Alıştırma verilerinin koşturulmasında hedeflenen RMSE ve en büyük iterasyon değerleri sırasıyla 0,01 ve 10.000 olarak seçilmiştir.

YSA da aktivasyon fonksiyonu bir nöron üzerinde etkin olan ağırlıklandırılmış sinyalleri ifade etmekte kullanılır(Negnevitsky, 2002). Artı ve eksi sonsuz aralığında değer alabilen bir girdiyi $[0,1]$ arasında bir değerde veren sigmoid fonksiyonu tercih edilmektedir. Analizde, aktivasyon fonksiyonu sigmoid (lojistik) fonksiyonu kullanılmıştır.

\section{BULGULAR}

\subsection{Analiz Sonuçları}

FO analizi için seçilen 15 parametre kategorik olarak sınıflandırılmış ve her bir parametrenin alt kategorisindeki frekans oranları hesaplanmıştır. FO yöntemine göre Tablo 1'deki gibi frekans değerleri normalleştirilerek parametreler için elde

Tablo 1. Parametlere Ait Frekans Oranları (FO).

Table 1. Frequency Ratios of Parameters (FR).

\begin{tabular}{|c|c|c|c|c|c|c|c|}
\hline PARAMETRE & & $A$ & $a=A(\%)$ & B & $b=B(\%)$ & $F O=b / a$ & NFO \\
\hline \multirow[t]{8}{*}{ Arazi Kullanımı } & $\mathrm{Su}$ & 38118 & 0,108 & 0 & 0,000 & 0,000 & 0 \\
\hline & Taşlık & 40219 & 0,171 & 2 & 0,228 & 1,329 & 99 \\
\hline & İskân & 81051 & 1,405 & 5 & 0,569 & 0,405 & 30 \\
\hline & Orman Toprağı & 173674 & 4,202 & 35 & 3,986 & 0,949 & 71 \\
\hline & Verimli Orman & 864403 & 25,065 & 140 & 15,945 & 0,636 & 47 \\
\hline & Bozuk Orman & 1096782 & 32,083 & 261 & 29,727 & 0,927 & 69 \\
\hline & Ziraat & 1258432 & 36,966 & 435 & 49,544 & 1,340 & 100 \\
\hline & $\Sigma$ & 3552679 & 100,000 & 878 & 100,000 & 5,586 & \\
\hline \multirow[t]{9}{*}{ Bakı } & $\mathrm{K}$ & 554343 & 15,604 & 147 & 16,743 & 1,073 & 79 \\
\hline & KD & 516645 & 14,542 & 170 & 19,362 & 1,331 & 99 \\
\hline & $\mathrm{D}$ & 357050 & 10,050 & 86 & 9,795 & 0,975 & 72 \\
\hline & GD & 274831 & 7,736 & 92 & 10,478 & 1,355 & 100 \\
\hline & G & 319651 & 8,997 & 74 & 8,428 & 0,937 & 69 \\
\hline & GB & 476378 & 13,409 & 82 & 9,339 & 0,697 & 52 \\
\hline & B & 482789 & 13,589 & 119 & 13,554 & 0,997 & 74 \\
\hline & $\mathrm{KB}$ & 570992 & 16,072 & 108 & 12,301 & 0,765 & 57 \\
\hline & $\Sigma$ & 3552679 & 100,000 & 878 & 100,000 & 8,129 & \\
\hline \multirow[t]{11}{*}{ Yükselti } & $0 \leq$ mesafe $\leq 250$ & 375223 & 10,563 & 79 & 8,998 & 0,852 & 60 \\
\hline & $250<$ mesafe $\leq 500$ & 766677 & 21,581 & 272 & 30,979 & 1,435 & 100 \\
\hline & $500<$ mesafe $\leq 750$ & 642950 & 18,096 & 188 & 21,412 & 1,183 & 83 \\
\hline & $750<$ mesafe $\leq 1000$ & 530716 & 14,940 & 131 & 14,920 & 0,999 & 70 \\
\hline & $1000<$ mesafe $\leq 1250$ & 406821 & 11,450 & 89 & 10,137 & 0,885 & 62 \\
\hline & $1250<$ mesafe $\leq 1500$ & 317046 & 8,924 & 45 & 5,125 & 0,574 & 40 \\
\hline & $1500<$ mesafe $\leq 1750$ & 254674 & 7,167 & 39 & 4,442 & 0,620 & 43 \\
\hline & $1750<$ mesafe $\leq 2000$ & 166696 & 4,692 & 27 & 3,075 & 0,655 & 46 \\
\hline & $2000<$ mesafe $\leq 2250$ & 80517 & 2,267 & 8 & 0,911 & 0,402 & 28 \\
\hline & $2250<$ mesafe $\leq 2442$ & 11359 & 0,319 & 0 & 0,000 & 0,000 & 0 \\
\hline & $\Sigma$ & 3552679 & 100,000 & 878 & 100,000 & 7,606 & \\
\hline
\end{tabular}


Tablo 1: (devamı). Parametrelere Ait Frekans Oranları.

Table 1: Frequency Ratios of Parameters.

\begin{tabular}{|c|c|c|c|c|c|c|c|}
\hline \multicolumn{2}{|l|}{ PARAMETRE } & \multirow{2}{*}{$\begin{array}{l}\boldsymbol{A} \\
1193017\end{array}$} & \multirow{2}{*}{$\begin{array}{l}a=A(\%) \\
33,581\end{array}$} & \multirow{2}{*}{$\begin{array}{l}\text { B } \\
290\end{array}$} & \multirow{2}{*}{$\begin{array}{l}\boldsymbol{b}=\boldsymbol{B}(\%) \\
33,030\end{array}$} & \multirow{2}{*}{$\begin{array}{l}F O=b / a \\
0,984\end{array}$} & \multirow{2}{*}{$\begin{array}{l}\text { NFO } \\
95\end{array}$} \\
\hline Plan Eğriselliği & İç Bükey & & & & & & \\
\hline & Düz & 949784 & 26,734 & 242 & 27,563 & 1,031 & 100 \\
\hline & Dış Bükey & 1409878 & 39,685 & 346 & 39,408 & 0,993 & 96 \\
\hline & $\Sigma$ & 3552679 & 100 & 878 & 100 & 3,008 & \\
\hline \multirow[t]{4}{*}{$\overline{\text { Profil Eğriselliği }}$} & Dış Bükey & 1314446 & 36,999 & 321 & 36,560 & 0,988 & 97 \\
\hline & Düz & 986477 & 27,767 & 249 & 28,360 & 1,021 & 100 \\
\hline & İç Bükey & 1251756 & 35,234 & 308 & 35,080 & 0,996 & 97 \\
\hline & $\Sigma$ & 3552679 & 100,000 & 878 & 100,000 & 3,005 & \\
\hline \multirow[t]{4}{*}{ Pürüzlülük } & Düşük & 101773 & 2,865 & 1 & 0,114 & 0,040 & 4 \\
\hline & Orta & 1231444 & 34,662 & 279 & 31,777 & 0,917 & 84 \\
\hline & Yüksek & 2219462 & 62,473 & 598 & 68,109 & 1,090 & 100 \\
\hline & $\Sigma$ & 3552679 & 100,000 & 878 & 100,000 & 2,047 & \\
\hline \multirow[t]{7}{*}{$T W I$} & $4<$ spi $\leq 5$ & 39955 & 1,125 & 14 & 1,595 & 1,418 & 100 \\
\hline & $5<$ spi $\leq 6$ & 385503 & 10,851 & 102 & 11,617 & 1,071 & 75 \\
\hline & $6<$ spi $\leq 8$ & 2220653 & 62,506 & 565 & 64,351 & 1,030 & 73 \\
\hline & $8<$ spi $\leq 9$ & 543865 & 15,309 & 128 & 14,579 & 0,952 & 67 \\
\hline & $9<$ spi $\leq 12$ & 246382 & 6,935 & 48 & 5,467 & 0,788 & 56 \\
\hline & $12<$ spi $\leq 21$ & 116321 & 3,274 & 21 & 2,392 & 0,731 & 51 \\
\hline & $\Sigma$ & 3552679 & 100,000 & 878 & 100,000 & 5,989 & \\
\hline \multirow[t]{6}{*}{$\overline{S P I}$} & $0<$ spi $\leq 1$ & 1127844 & 31,746 & 262 & 29,841 & 0,940 & 87 \\
\hline & $1<$ spi $\leq 2$ & 1241394 & 34,942 & 331 & 37,699 & 1,079 & 100 \\
\hline & $2<$ spi $\leq 3$ & 830793 & 23,385 & 198 & 22,551 & 0,964 & 89 \\
\hline & $3<$ spi $\leq 4$ & 200744 & 5,650 & 47 & 5,353 & 0,947 & 88 \\
\hline & $4<$ spi $\leq 10.8$ & 151904 & 4,276 & 40 & 4,556 & 1,065 & 99 \\
\hline & $\Sigma$ & 3552679 & 100,000 & 878 & 100,000 & 4,996 & \\
\hline \multirow[t]{6}{*}{ LS } & 1 & 992005 & 27,923 & 42 & 4,784 & 0,171 & 1 \\
\hline & 2 & 1729878 & 48,692 & 26 & 2,961 & 0,061 & 0 \\
\hline & 3 & 522653 & 14,712 & 125 & 14,237 & 0,968 & 7 \\
\hline & 4 & 155604 & 4,380 & 513 & 58,428 & 13,340 & 100 \\
\hline & 5 & 152539 & 4,294 & 172 & 19,590 & 4,563 & 34 \\
\hline & $\Sigma$ & 3552679 & 100,000 & 878 & 100,000 & 19,103 & \\
\hline \multirow[t]{6}{*}{ Drenaj Yoğunluğu } & $0.0013 \leq$ yoğunluk $\leq 1$ & 119240 & 3,356 & 19 & 2,164 & 0,645 & 58 \\
\hline & $1<$ yoğunluk $\leq 2$ & 636630 & 17,920 & 139 & 15,831 & 0,883 & 79 \\
\hline & $2<$ yoğunluk $\leq 3$ & 1124859 & 31,662 & 291 & 33,144 & 1,047 & 94 \\
\hline & $3<$ yoğunluk $\leq 4$ & 1043527 & 29,373 & 288 & 32,802 & 1,117 & 100 \\
\hline & $4<$ yoğunluk $\leq 8.14$ & 628423 & 17,689 & 141 & 16,059 & 0,908 & 81 \\
\hline & $\Sigma$ & 3552679 & 100,000 & 878 & 100,000 & 4,600 & \\
\hline \multirow[t]{6}{*}{ Drenaj Mesafe } & $0 \leq$ mesafe $\leq 100$ & 1574597 & 44,321 & 389 & 44,305 & 1,000 & 94 \\
\hline & $100<$ mesafe $\leq 200$ & 1097882 & 30,903 & 284 & 32,346 & 1,047 & 99 \\
\hline & $200<$ mesafe $\leq 300$ & 581830 & 16,377 & 153 & 17,426 & 1,064 & 100 \\
\hline & $300<$ mesafe $\leq 400$ & 223259 & 6,284 & 39 & 4,442 & 0,707 & 67 \\
\hline & $400<$ mesafe $\leq 807$ & 75111 & 2,114 & 13 & 1,481 & 0,700 & 66 \\
\hline & $\Sigma$ & 3552679 & 100,000 & 878 & 100,000 & 4,518 & \\
\hline Yol Mesafe & $0 \leq$ mesafe $\leq 100$ & 1809191 & 50,925 & 533 & 60,775 & 1,193 & 100 \\
\hline & $100<$ mesafe $\leq 200$ & 724802 & 20,402 & 199 & 22,691 & 1,112 & 93 \\
\hline & $200<$ mesafe $\leq 300$ & 288836 & 8,130 & 45 & 5,131 & 0,631 & 53 \\
\hline & $300<$ mesafe $\leq 400$ & 152536 & 4,294 & 35 & 3,877 & 0,903 & 76 \\
\hline & $400<$ mesafe $\leq 2150$ & 577314 & 16,250 & 66 & 7,526 & 0,463 & 39 \\
\hline & $\Sigma$ & 3552679 & 100,000 & 878 & 100,000 & 4,303 & \\
\hline Yol Yoğunluk & $0 \leq$ yoğunluk $\leq 0.13$ & 353840 & 9,960 & 22 & 2,506 & 0,252 & 15 \\
\hline & $0.13<$ yoğunluk $\leq 2$ & 760868 & 21,417 & 104 & 11,845 & 0,553 & 32 \\
\hline & $2<$ yoğunluk $\leq 4$ & 786963 & 22,151 & 207 & 23,576 & 1,064 & 62 \\
\hline & $4<$ yoğunluk $\leq 6$ & 1076837 & 30,311 & 301 & 34,282 & 1,131 & 66 \\
\hline & $6<$ yoğunluk $\leq 9.67$ & 574171 & 16,162 & 244 & 27,790 & 1,720 & 100 \\
\hline & $\Sigma$ & 3552679 & 100,000 & 878 & 100,000 & 4,720 & \\
\hline Ĕgim & $0 \leq$ eğim $\leq 10$ & 200273 & 5,637 & 12 & 1,367 & 0,242 & 19 \\
\hline & $10<$ eğim $\leq 20$ & 561259 & 15,798 & 123 & 14,009 & 0,887 & 68 \\
\hline & $20<$ eğim $\leq 30$ & 1132273 & 31,871 & 288 & 32,802 & 1,029 & 79 \\
\hline & $30<$ eğ im $\leq 40$ & 1322707 & 37,231 & 346 & 39,408 & 1,058 & 81 \\
\hline & 40<eğim & 336167 & 9,462 & 109 & 12,415 & 1,312 & 100 \\
\hline & $\Sigma$ & 3552679 & 100,000 & 878 & 100,000 & 4,529 & \\
\hline
\end{tabular}


Tablo 1: (devamı). Parametrelere Ait Frekans Oranları.

Table 1: Frequency Ratios of Parameters.

\begin{tabular}{|c|c|c|c|c|c|c|c|}
\hline PARAMETRE & & $A$ & $a=A(\%)$ & B & $b=B(\%)$ & $F O=b / a$ & NFO \\
\hline \multirow[t]{7}{*}{ Jeoloji } & Baz. And. dasit lav ve piroklastları & 1115698 & 31,404 & 468 & 53,303 & 1,697 & 100 \\
\hline & $\begin{array}{l}\text { Bazalt andezit lav ve piroklastları } \\
\text { kum çakıl taşı }\end{array}$ & 164597 & 4,633 & 37 & 4,214 & 0,910 & 54 \\
\hline & Riyodasit dasit lav ve pirokllastları & 559470 & 15,748 & 87 & 9,909 & 0,629 & 37 \\
\hline & Andezit bazalt lav ve piroklastları & 621903 & 17,505 & 135 & 15,376 & 0,878 & 52 \\
\hline & Alüvyon & 111535 & 3,139 & 7 & 0,797 & 0,254 & 15 \\
\hline & Kaçkar Granitoyidi & 979476 & 27,570 & 144 & 16,401 & 0,595 & 35 \\
\hline & $\Sigma$ & 3552679 & 100,000 & 878 & 100,000 & 4,963 & \\
\hline
\end{tabular}

edilen NFO değerleri, her bir parametre sınıfına atanmış ve tüm parametre değerleri üst üste çakıştırılarak heyelan duyarlılık indeksi (HDİ) elde edilmiștir. Şekil 6'daki FR duyarlılık haritasına göre; havzanın \% 0,20 si i çok düşük, \%11,47 si düşük, $\% 46,32$ si orta, \%40,86's1 yüksek ve \%1,15 i çok yüksek heyelan duyarlılığına sahiptir.

LR analiz sonuçları olan $\beta$ regresyon katsayısı, $S H$ standart hata, Wald testi değeri ve Sig anlamlılık değerleri Tablo 2'de verilmiştir. Elde edilen $\beta$ regresyon katsayıları harita cebri analiz araçları ile regresyon formülünde yerine yazılarak heyelan duyarlılık haritası Şekil 6'daki gibi elde edilmiştir. Elde edilen duyarlılık haritası eşit dağılımlı olarak beşe ayrılmıştır. Buna göre havzanın \%4,55'i çok düşük, \%18,65 düşük, \%17,45'i orta, \%43,37'si yüksek ve \%15,99'u çok yüksek heyelan duyarlılığına sahiptir.

YSA analizi ile heyelan duyarlılık haritası Şekil 7'daki gibi oluşturulmuştur. Elde edilen duyarlılık haritasına göre havzanın \%6,52’ si çok düşük, \%7,20'si düşük, \%18,9'u orta, \%36,02'si yüksek ve \%31,35'i ise çok yüksek duyarlılıktadır.

\subsection{Doğruluk Analizi}

Modelin genel doğruluğunun analizi kapsamında heyelanların modellerden üretilen duyarlılık haritası üzerindeki dağılımları Tablo 3'deki gibi özetlenmiştir. Analizlerin genel doğruluğu incelenirken yüksek ve çok yüksek alanlara dağılan heyelanların

Tablo 2: Lojistik Regresyon Model Sonuçları.

Table 2: Logistic Regression Model Results.

\begin{tabular}{|c|c|c|c|c|c|c|}
\hline PARAMETRE & $\boldsymbol{\beta}$ & S.H. & Wald & $d f$ & Sig. & $\operatorname{Exp}(\beta)$ \\
\hline Kaçkar Granotiyodi & $-0,824$ & 0,222 & 13,797 & 1,000 & 0,000 & 0,439 \\
\hline Bazalt Andezit Lav ve Piroklastları & 1,017 & 0,221 & 21,116 & 1,000 & 0,000 & 2,766 \\
\hline Bazalt Andezit Lav ve Piroklastları Kum Çakıl Taşı & 0,235 & 0,352 & 0,445 & 1,000 & 0,005 & 1,265 \\
\hline Riyodasit Dasit Lav ve Piroklasları & 0,313 & 0,235 & 1,769 & 1,000 & 0,000 & 1,367 \\
\hline Andezit Bazalt Lav ve Piroklastları & 0,237 & 0,288 & 0,680 & 1,000 & 0,001 & 1,268 \\
\hline Alüvyon & $-0,814$ & 0,663 & 1,506 & 1,000 & 0,020 & 0,443 \\
\hline Bozuk Orman & 0,409 & 0,222 & 3,391 & 1,000 & 0,000 & 1,505 \\
\hline iskân & 0,103 & 2,684 & 0,023 & 1,000 & 0,000 & 1,108 \\
\hline Orman Toprağı & 0,833 & 0,436 & 3,642 & 1,000 & 0,000 & 2,300 \\
\hline $\mathrm{Su}$ & $-15,720$ & $40.192,970$ & 0,000 & 1,000 & 1,000 & 0,000 \\
\hline Taşlık & $-0,528$ & 1,317 & 2,161 & 1,000 & 0,000 & 1,696 \\
\hline Ziraat & 0,520 & 0,231 & 5,080 & 1,000 & 0,024 & 1,894 \\
\hline Verimli Orman & $-1,130$ & 0,208 & 29,412 & 1,000 & 0,009 & 0,323 \\
\hline Bakı & 0,001 & 0,001 & 1,873 & 1,000 & 0,266 & 1,001 \\
\hline Drenaja Olan Mesafe & 0,000 & 0,001 & 0,006 & 1,000 & 0,939 & 1,000 \\
\hline Drenaj Yoğunluğu & 5,603 & 1,213 & 8,059 & 1,000 & 0,037 & 271,286 \\
\hline Yükselti & 0,000 & 0,000 & 0,153 & 1,000 & 0,753 & 1,000 \\
\hline Ls Faktörü & 0,000 & 0,004 & 3,477 & 1,000 & 0,062 & 1,000 \\
\hline Profil Eğriselliği & 0,217 & 0,145 & 2,242 & 1,000 & 0,034 & 1,242 \\
\hline Plan Eğriselliği & 0,157 & 0,150 & 1,107 & 1,000 & 0,021 & 1,170 \\
\hline Pürüzlülük & 7,953 & 3,417 & 5,416 & 1,000 & 0,000 & $2.843,108$ \\
\hline Eğim & 0,344 & 0,148 & 5,370 & 1,000 & 0,020 & 0,709 \\
\hline Akarsu Aşındırma Gücü Indeksi & 0,288 & 0,332 & 0,750 & 1,000 & 0,042 & 1,334 \\
\hline Topoğrafik Nemlilik Indeksi & 0,183 & 0,286 & 0,411 & 1,000 & 0,000 & 0,832 \\
\hline Yol Yoğunluğu & 0,112 & 0,046 & 5,881 & 1,000 & 0,002 & 1,119 \\
\hline Yola Olan Mesafe & $-0,002$ & 0,000 & 11,444 & 1,000 & 0,000 & 0,998 \\
\hline Sabit & $-6,092$ & 4,170 & 2,134 & 1,000 & 0,000 & 0,002 \\
\hline
\end{tabular}



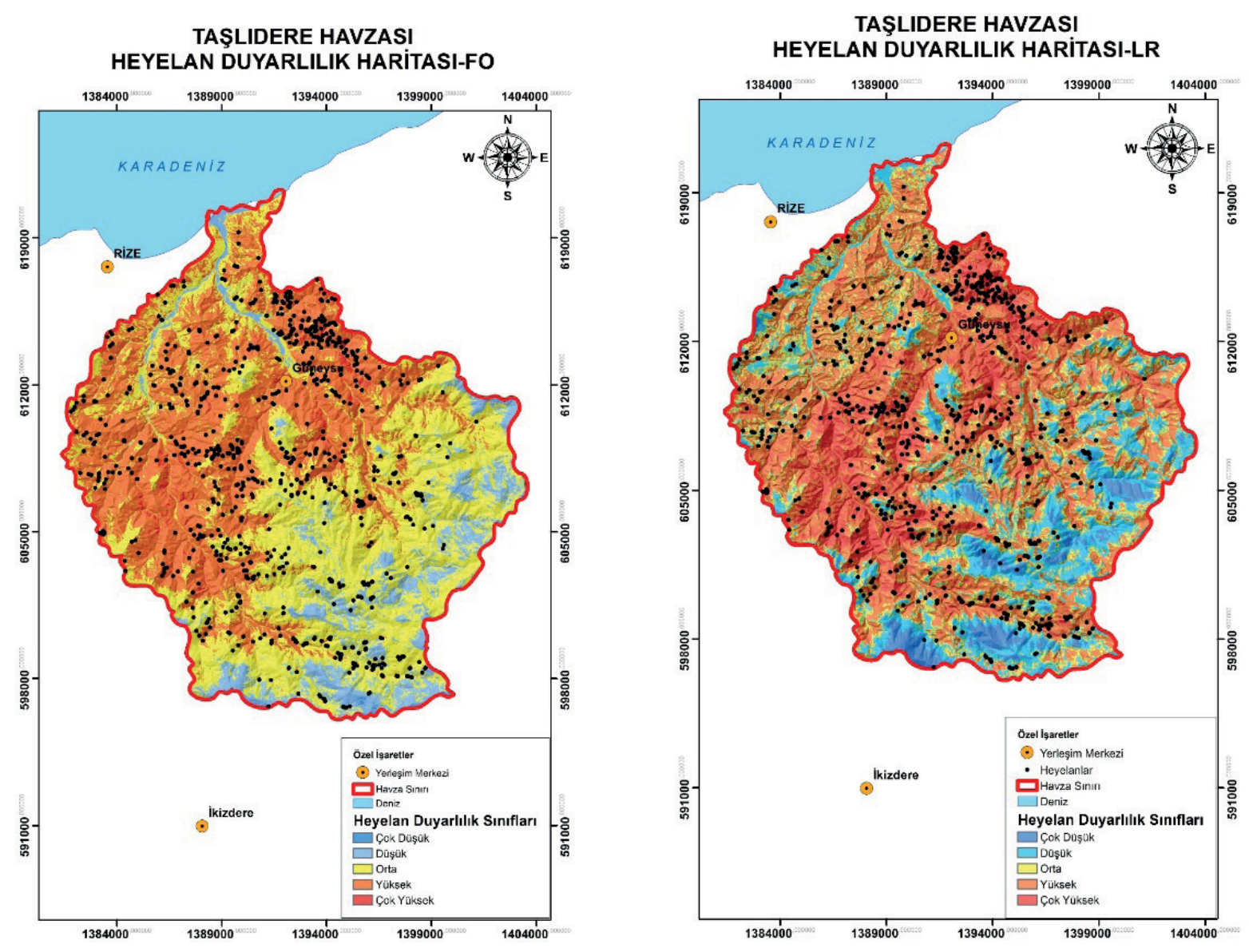

Şekil 6: Taşlıdere Havzası Heyelan Duyarlılık Haritası- (a) FO ve (b) LR.

Figure 6: Taşlıdere Basin Landslide Susceptibility Map- (a) FR and (b) LR.

yüzdeleri toplamı alınmıştır. Buna göre genel doğruluk FO için 65,3, LR için 83,49 ve YSA için 84,17 olarak elde edilmiştir.

Heyelan duyarlık analizlerinin performans değerlendirilmesi için sınıflama eşik değerinden bağımsız bir yöntem olan ROC (Receiver-Operating Characteristics) eğrileri kullanılmıştır. ROC eğrileri, farklı eşik değerleri için hesaplanmış model hassasiyet (susceptibility) -doğru pozitif bölüntü- değerlerine karşıllı model özgüllük (specificity) -doğru negatif bölüntüdeğerlerinin bir grafik üzerinde gösterilmesiyle oluşturulur (Daelo, 1993). Her bir model için yapılan ROC analizleri sonucunda AUC değerleri FO yöntemi için 0,72 , LR yöntemi 0,83 için ve YSA yöntemi için ise 0,87 olarak hesaplanmıştır (Şekil 8).

\section{SONUÇLAR}

Rize ili Taşlıdere Havzası içerisinde can ve mal kaybına yol açan kütle hareketleri ağırlıklı olarak sı̆̆ heyelanlar şeklinde gelişmektedir. Drenaj alanının içerisinde yer aldığı bölge Türkiye'nin en çok yağış alan bölgesidir. Heyelanlar vadi tabanlarında ve nemliliğin yüksek olduğu alanlarda meydana gelmektedir. Dereler ise kıyı erozyonuna sebep olmaktadır. Ayrıca yollar yamaçların alt kesimlerine yapıldığında yamaçların topuk desteğini kaldırarak heyelana sebep vermektedir. Bu çalışmada drenaj alanı içerisinde meydana gelen bu sı̆̆ heyelanlara ilişkin heyelan duyarlılık analizleri FO, LR ve YSA yöntemleri ile gerçekleştirilmiştir.

Taşlıdere havzasında 878 noktasal heyelan envanteri kullanılmıştır. Yapılan analizler için faktörleri temsil eden 15 adet bağımsız değişken (arazi kullanım durumu, jeoloji, yükselti, eğim, bak1, plan eğrisellik, profil eğrisellik, pürüzlülük, TWI, SPI, LS faktörü, yola olan mesafe, yol yoğunluğu, drenaj yoğunluğu, drenaja olan mesafe) belirlenmiştir. LR ve YSA analizlerinde arazi kullanımı ve jeoloji parametrelerinin her bir alt sınıfı birbirinden bağımsız olarak ele alındığı için toplam 26 adet bağımsız değişken kullanılmıştır. 


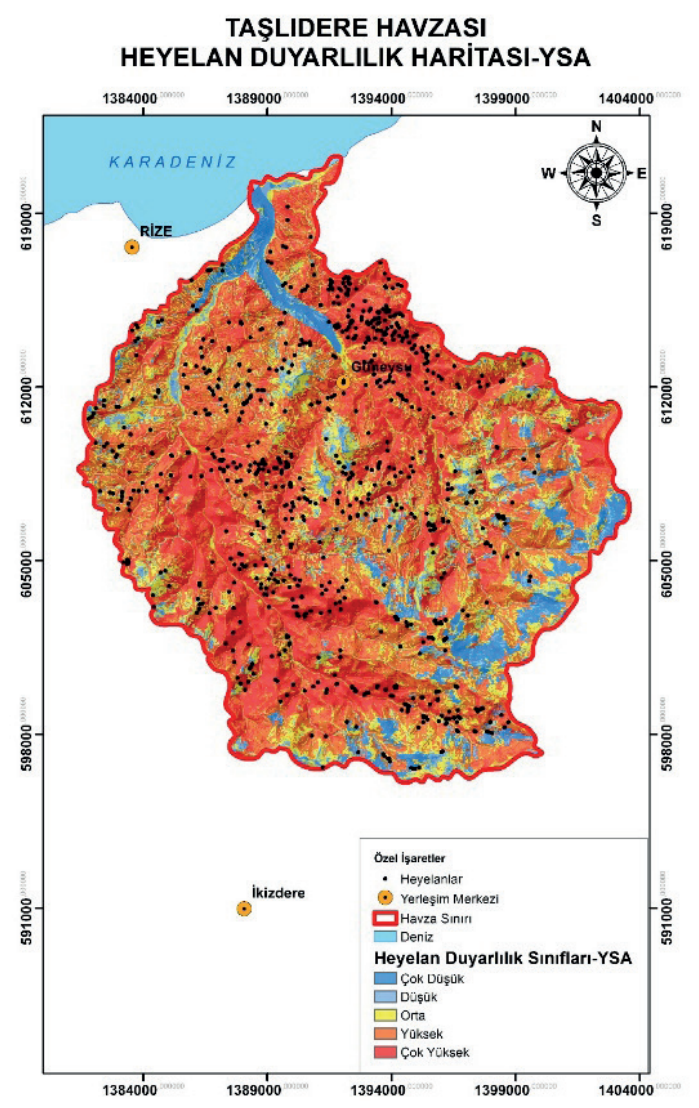

Şekil 7: Rize Illi Taşlıdere Havzası Heyelan Duyarlılık Haritası-YSA Figure 7: Rize Province Taşlıdere Basin Landslide Susceptibility Map- the ANN.
FO tekniği kullanılarak 15 parametrenin bindirilmesi ile üretilen duyarlılık haritası 5 eşit sınıfa ayrılmıştır. Buna göre havzanın \% 0,20'si çok düşük, \%11,47'si düşük, \%46,32'si orta, $\% 40,86$ 'sı yüksek ve $\% 1,15$ 'i çok yüksek heyelan duyarlılığına sahiptir. Modelin genel doğruluğu 65,3 ve AUC değeri 0,72 olarak hesaplanmıştır.

YSA tekniğinde gizli katman sayısı 1, nöron sayısı 18 seçilerek 26-18-1 ağ yapısı, "momentum faktör" 0,5, RMS 0,001 , iterasyon sayıs 10.000 ve aktivasyon fonksiyon olarak da sigmodial fonksiyon seçilerek heyelan duyarlılık haritası elde edilmiştir. Elde edilen harita eşit dağılımlı olarak 5 sınıfa ayrılmış ve havzanın $\% 6,52$ ' si çok düşük, $\% 7,20$ 'si düşük, $\% 18,9$ 'u orta, $\% 36,02$ 'si yüksek ve $\% 31,35$ 'i ise çok yüksek duyarlılıktadır. Modelin performans değerlendirmesi kapsamındaki ROC Curve Analizi sonucunda AUC değeri 0,87 olarak hesaplanmıştır.

LR tekniğinde, veri matrisinde eşit sayıda heyelan olan ve heyelan olmayan noktalar seçilerek eğitim seti oluşturulmuş ve analiz gerçekleştirilerek regresyon katsayıları hesaplanmıştır. Elde edilen katsayılar parametreleri ile çarpıldıktan sonra harita cebri ile denklemde tanımlanarak heyelan duyarlılık haritası oluşturulmuştur. Duyarlılık haritası; havzanın \% 4.55'i çok düşük, \%18.65 düşük, \%17.45'i orta, \%43.37'si yüksek, \%15.99'u çok yüksek heyelan duyarlılı̆̆ına sahiptir. Modelin

Tablo 3: Heyelanların FO, LR ve YSA ile elde edilen duyarlılık haritası üzerindeki dağılımı.

Table 3: Distribution of landslides on the susceptibility map obtained by FR, LR and ANN.

\begin{tabular}{lllllll}
\hline & FO & & LR & & YSA \\
\hline Duyarııık Sınııı & Heyelanlı Noktalar & Oran (\%) & Heyelanlı Noktalar & Oran (\%) & Heyelanlı Noktalar & Oran (\%) \\
\hline Çok Düşük & 0 & 0,00 & 4 & 0,46 & 10 & 1,14 \\
Düşük & 24 & 2,74 & 58 & 6,61 & 25 & 2,85 \\
Orta & 280 & 31,96 & 83 & 9,45 & 104 & 11,84 \\
Yüksek & 545 & 61,99 & 410 & 46,70 & 318 & 36,22 \\
Çok Yüksek & 29 & 3,31 & 323 & 36,79 & 421 & 878 \\
I & 878 & 100 & 878 & 100 & 47,95 & 100 \\
\hline
\end{tabular}
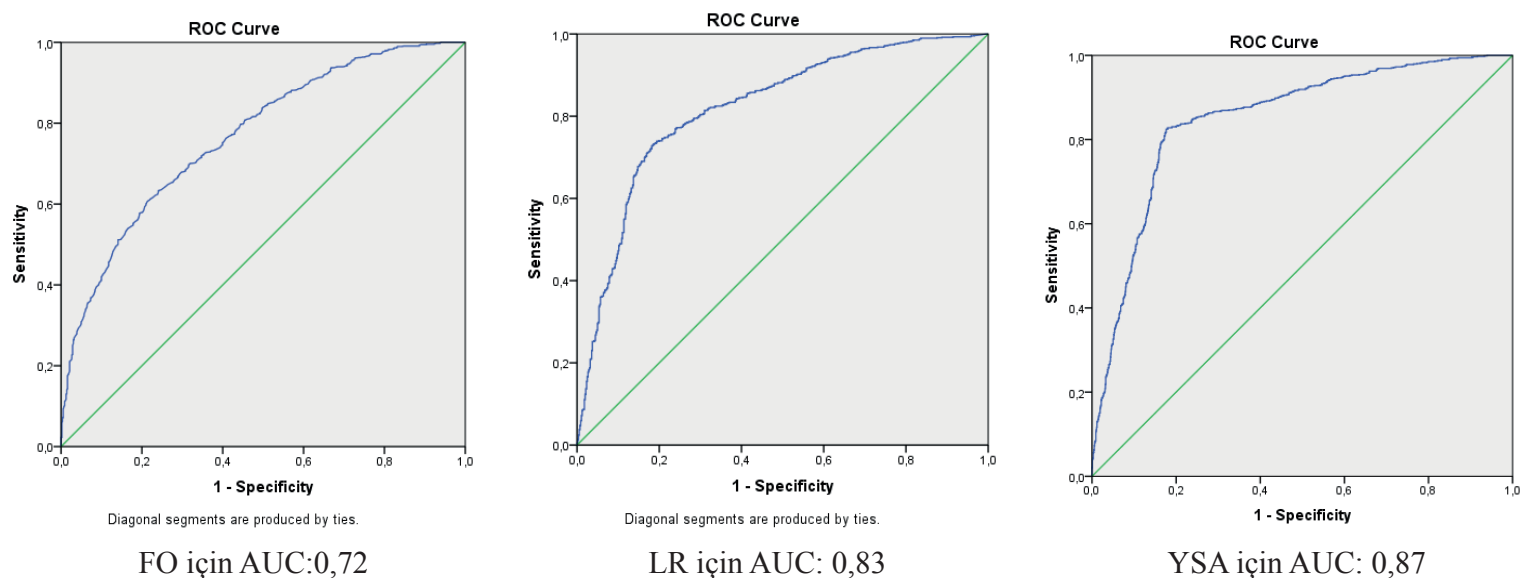

YSA için AUC: 0,87

Şekil 8: FO, LR ve YAS modelleri ROC analizi.

Figure 8: ROC analysis of $F R, L R$ and $A N N$ models. 
AUC değeri 0,83 olarak belirlenmiştir. Katsayıları incelendiğinde Jeolojik birimlerden alüvyon, bazalt andezit lav ve piroklastları kum çakıl taşı, riyodasit dasit lav ve piroklastları, andezit bazalt lav ve piroklastları ile su, bakı, drenaja olan mesafe, yükselti, plan eğriselliği ve AGİ haricindeki tüm faktörlerin Wald değerinin 2'den büyük ve anlamlı oldukları görülmüştür. Dolayısıyla bu parametrelerin havza üzerindeki heyelan duyarlılık analizlerinde kullanılmasının bir etkisi olmadığ görülmüştür. Diğer yandan $\operatorname{Exp}(\beta)$ değerlerine göre 1'e en uzak drenaj yoğunluğu, pürüzlülük, bazalt andezit lav ve piroklastlarının en etkin faktör olduğu gözlenmiştir. $\beta$ katsayıları incelendiğinde, drenaj yoğunluğu ve pürüzlülük katsayısı en büyük pozitif değerler olarak heyelan duyarlılığını arttırıcı olurken, Kaçkar gronotoyidi, taşlık ve verimli orman alanları da en yüksek negatif katsayı değerlerini alarak heyelan duyarlılığını azaltıcı olarak etkimektedir.

Duyarlılık haritalamalarının sonucunda AUC değerleri incelendiğinde, YSA modelinin performansının LR modelinin performansına oldukça yakın olduğu ve birbirini desteklediği gözlenmiştir. YSA yapısında ağırlık katsayıları ve parametrelerin ne kadar etkilendiği bilinmemektedir. YSA, biyolojik sinir ağlarına benzer yaklaşımla bilgisayara aktararak, üretilen çıktıların dışardan alınarak içeride anlamlandırmak suretiyle yine dışarıya bir çıktı vermesidir. YSA analizi içeri alınan verilerden sonuçların nasıl elde edildiğini açıklamamaktadır. YSA, AUC değerlerine göre daha doğru bir sonuç vermekte, ancak karmaşık bir analiz olduğundan ağın iyi tasarlanması gerekmektedir. Aşırı öğrenme yaşandığı takdirde verilen sonuçlar iyimser olacağından, ağ tasarımının oluşturulması oldukça detaylı çalışılması gereken bir konudur. Diğer yandan LR yönteminde ise parametrelerin ağırlık katsayıları ve analize etkisi tek tek görülebilmektedir. Havza için kullanılabilecek parametrelerin kestirimi açısından oldukça verimli sonuçlar vermekte ve YSA'ya göre daha kolay uygulanabilir bir yöntem olduğu gözlenmiştir.

Drenaj alanının olduğu bölgede iskân ve ziraat alanlarına yakın ormanlarda sosyal baskıdan dolayı tahribat oluşmaktadır. $\mathrm{Bu}$ çalışmada ziraat alanlarının çoğunluğunu çaylık alanlar oluşturmakta olup bu alanların büyük bölümü orman alanlarının açılmasıyla oluşturulmuştur. Bu da havzada sığ heyelanlara ilişkin gerçekleşme frekansının artmasına sebep olmaktadır. Bu sebeple orman sınırları içerisindeki yerleşim ve ziraat alanları yakınındaki bozuk orman sahalarının sosyal baskıdan arındırılarak yeniden orman özelliği kazandırılmalıdır.

Çalışma alanındaki orman alanları çoğunlukla dik ve dağlık arazi kısmındadır. Eğim yüksek olduğu halde, orman sahalarında heyelana duyarlı alanların az olduğu belirlenmiştir. Bu kapsamda ormanların koruyucu fonksiyonlarından yararlanılmalı ve heyelanların frekansını en aza indirmek için orman alanlarının tahrip edilmesine, doğal yapılarını kaybederek kapalılıklarını yitirmesine izin verilmemeli ve heyelan duyarlılığı yüksek kısımlarında da ormanın koruyucu fonksiyonundan yararlanılmalıdır. Amenajman planları oluşturulurken heyelan duyarlılık haritaları değerlendirilerek ormanların heyelanı önleme fonksiyonları mutlaka göz önüne alınmalıdır.

Heyelan duyarlılık haritalarının üretilmesi, yol yapımı ve yerleşim planlarının hazırlanması, heyelanın sebep olacağı can ve mal kayıplarının azaltılabilmesi, afet yönetim planlamasının kontrollü yapılabilmesi bakımından oldukça önemlidir. Duyarlılık haritasının üretimi tek başına yeterli olmayıp üretilen haritanın doğruluğu en etken faktördür. Bunun için kullanılan parametrelerin ve heyelan envanter verisinin doğruluğu oldukça önemlidir. Duyarlılık parametrelerinin daha hassas üretilebilmesi, parametrelerin konumsal doğruluğunun yüksek olması ile doğrudan ilişkilidir. Bu nedenle çözünürlüğü daha yüksek sayısal yükseklik modelleri daha etkin sonuçlar verebilir ve havza bazında insansız hava araçları ile yüksek hassasiyetli SYM elde edilebilir. Ayrıca heyelan envanterinin güncel olması da sonucu etkilediğinden, bu haritalarda radar görüntülerinden ya da yüksek çözünürlüklü uydu görüntülerinden yararlanılarak daha yüksek duyarlılık elde edilebilir.

Teşekkür: Çölleşme ve Erozyonla Mücadele Genel Müdürlüğü'nün Rize ili Güneysu Havzası Heyelan Duyarlılık Haritalaması Projesi kapsamında oluşturulan sığ heyelan envanteri verisi G. Altürk'ün yüksek lisans tez çalışmasında kullanılmıştır.

Hakem Değerlendirmesi: Dış bağımsız.

Yazar Katkıları: : Çalışma Konsepti/Tasarım- G.A.; Veri Toplama- G.A.; Veri Analizi/Yorumlama- A.Ç.A.; Yazı Taslağı- G.A.; İçeriğin Eleştirel İncelemesi- A.Ç.A.; Son Onay ve Sorumluluk- A.Ç.A., G.A.

Çıkar Çatışması: Yazarlar çıkar çatışması bildirmemiştir.

Finansal Destek: Yazarlar bu çalışma için finansal destek almadığını beyan etmiştir.

Peer-review: Externally peer-reviewed.

Author Contributions: Conception/Design of Study- G.A.; Data Acquisition- G.A.; Data Analysis/Interpretation- A.Ç.A.; Drafting Manuscript- G.A.; Critical Revision of ManuscriptA.Ç.A.; Final Approval and Accountability- A.Ç.A., G.A.

Conflict of Interest: The authors have no conflict of interest to declare.

Grant Support: The authors declared that this study has received no financial support.

\section{KAYNAKÇA/REFERENCES}

Aleotti, P., \& Chowdhury, R. (1999). Landslide Hazard Assessment: Summary Review and New Perspectives. Bulletin of Engineering Geology and the Environment, 58(1), 21-44.

Alkevli, T. (2015). Heyelan duyarlılık haritalarının üretilmesinde örneklem stratejileri ve bazı karar verme ağaçları algoritmalarının kullanımın üzerine bir araştırma. Ankara: Hacettepe Üniversitesi. 
Altürk, G. (2019). Coğrafi bilgi sistemleri ortamında makine öğrenmesi ve istatistiksel yöntemler kullanılarak heyelan duyarlılık haritalarının üretilmesi: Rize Taşlıdere havzası örneği. Kocaeli, Gebze: Gebze Teknik Üniversitesi.

Arca, D., \& Kutoğlu, Ş. (2017). Frekans Oranı Metodu ile Heyelan Duyarlılık Haritasının Üretilmesi. TMMOB Harita ve Kadastro Mühendisleri Odast, 16. Türkiye Harita Bilimsel ve Teknik Kurultayl. Ankara. Harita Kadastro Mühendisleri Odası: https:// www.hkmo.org.tr/resimler/ekler/23443add7429229_ek.pdf adresinden alınd 1

Ayalew, L., \& Yamagishi, H. (2005). The application of GIS-based logistic regression for landslide susceptibility mapping in the Kakuda-Yahiko Mountains. Geomorphology, 65(1-2), 15-31.

Ayalew, L., Yamagishi, H., \& Ugawa, N. (2004). Landslide susceptibility mapping using GIS-based weighted linear combination, The case in Tsugawa area of Agano river,Niigata Prefecture,Japan. Landslides, 1(1), 73-81.

Barling, R. (1992). Saturation Zones and ephemerel on arable land in southeastern Australia. Unpublished Phd Dissertation. University of Melbourne.

Basher, I., \& Hajmeer, M. (2000). Artificial neural networks: fundamentals,computing, design, and application. Journal of Microbiological Methods, 1(43), 3-31.

Beven, K., \& Kirkby, M. (1979). A Physically Based, Variable Contributing Area Model of Basin Hydrology. Un modèle à base physique de zone d'appel variable de l'hydrologie du bassin versant. Hydrological Sciences Bulletin, (24), 43-69.

Bonham-Carter, G. (1994). Geographic Information Systems for Geoscientists, Modeling with GIS. Oxford: Pergamon Press.

Can, A. (2014). Yapay sinir ağları ile heyelan duyarlılık haritalarının üretilmesinde farklı algoritmaların kullanımının araştırılması. Hacettepe Üniversitesi Yüksek Lisans Tezi. Ankara: Hacettepe Üniversitesi.

Cruden, D. (1991). A simple definition of a landslide. Bulletin of the International Association Engineering Geology, 27-29.

Çan T., Tekin S. (2016). İl sınırları bazında heyelan duyarlılık haritaları: Mersin Adana Osmaniye ve Hatay Örnekleri. Ulusal Heyelan Sempozyumu. Ankara.

ÇEMGM, (2016-2). Giresun İli Bulancak Havzası Heyelan Duyarlılık Haritası ve Değerlendirme Projesi. Ankara.

ÇEMGM, (2016). Rize ili Güneysu Mikrohavzası Heyelan Duyarlılık ve Tehlike Haritası Yapım Projesi. Ankara.

Daelo, J. (1993). Receiver operating characteristic laboratory (ROCLAB):software for developing decision strategies that account for uncertainty. (2nd) International Symposium on Uncertainty Modeling and Analysis, (s. 318-315).

Eker, A., Dikmen, M., Cambazoğlu, S., Düzgün, Ş., \& Akgün, H. (2012). Bartın,Ulus ilçesi için yapay sinir ağı ve lojistik regresyon yöntemlerinin heyelan duyarlılık çalışmasına uygulanması ve karşılaştırılması. Gazi Üniversitesi Müh.Mim.Fak.Der., 27(1), 163173.
Ercanoglu, M. \& Temiz, F.A. (2011). Aplication of logistic regression and fuzzy operators to landslide susceptibility assesment in Azdavay. Environmental Earth Sciences, 64(4), 949-964.

Ercanoğlu, M. (2005). Landslide susceptibility assesment of SE Bartın (West Black Sea region,Turkey) by artificial neural networks. Natural Hazards and Earth System Sciences, 5(6), 979-992.

Erinç, S. (1965). Yağış Müessiriyeti Üzerine Bir Deneme ve Yeni Bir İndis. İstanbul: İstanbul Üniv.Coğ.Enst.Yayınları

Evans, I. (1972). General geomorphometry,derivatives of altitude and descriptive statistics In Chorley. Spatial Analysis in Geomorphology (s. 17-90). içinde Harper \& Row.

Frehner, M., Wasser, B., \& Schwitter, R. (2007). Sustainability and success monitoring in protection forests. Bern: Federal Office for the Environment.

Furniss, M., T.D., R., \& Yee, C. (1991). Road construction and maintenance. American Fisheries SocietyiSpecial Publication, 19, 297-324.

Gedikoğlu, A., Pelin, S., \& Özsayar, T. (1979). Tectonic evolution of the eastern Pontides in Mesozoic. Geocome-I, 428(1), 68.

Gomez, H., \& Kavzoğlu, T. (2005). Assesment of shallow lanslide susceptibility using artifucal neural networks in Jabonosa River Basin. Engineering Geology, 78(1-2), 11-27.

Gökçeoğlu, C., \& Ercanoğlu, M. (2001). Heyelan Duyarlılık Haritalarının Hazırlanmasında Kullanılan Parametrelere İlişkin Belirsizlikler. Yerbilimleri, 22(23), 189-206.

Güven, İ. (1998). Trabzon-C30 ve D30 Paftalart. Ankara: 1/100,000 Ölçekli Açınsama Nitelikli Türkiye Jeoloji Haritaları.

Harr, R., \& Nichols, R. (1993). Stabilizing forest roads to help restore fish habitats:a northwest Washington example. Fisheries, 18(4), 1822.

Hect-Nielsen, R. (1990). Neurocomputing. Addison-Wesley.

Horton, R. (1945). Erosional development of streams and their drainage basins: hydrophysical approach to quantitative morphology. Bulletin Of The Geological Society Of America, 56(3), 275-370.

Hosmer, D., Stanley Lemeshow, S., \& Sturtdivant, R. (2013). Applied Logitic Regression (3 b.). New Jersey: John Wiley \& Sons,.

Jacobs, R. (1998). Increased rates of convergence through learning rate adaptation. Neural Networks 1, 1(4), 295-307.

Kaastra, I., \& Boyd, M. (1996). Designing a neural network for forecasting financial and economic time series. Neurocomputing, $10(3), 215-236$.

Konar, A. (2005). Computational Intelligence: Principles, Techniques and Applications (2005 edition b.). Almanya: Springer.

Larsen, M., \& Parks, J. (1997). How wide is a Road?The association of roads and mass movements in a forested mountane environment. Earth Surface Process and Landforms, 22, 835-848.

Lee, S., \& Talib, J. (2005). Probabilistic landslide susceptibility and factor effect analysis. Environmental Geology, 47(7), 982-990.

Lee, S., Ryu, J., Min, K., \& Won, J. (2003). Landslide susceptibility analysis using GIS and artificial neural network. Earth Surface Processes and Landforms, 28(12), 1361-1376. 
Milewski, I., Markoski, B., Gorin, S., \& Jovanovski, M. (2009). Application of remote sensinh and GIS in detection of potential landslide areas. Scientific Symposium Geography and Sustainable Development, (s. 455-465). Ohrid,Republic of Macedonia.

Moore, I., \& Burch, G. (1986). Sediment transport capacity of sheet and rill flow:application of unit stream power theory. Water resources research, 22(8), 1350-1360.

Moore, I., \& Wilson, J. (1992). Length-slope factors for the Revised Universal Soil Loss Equation :simplified method for estimation. Journal of Soil and Water Conversation, 47(5), 423-428.

Moore, I., Grayson, R., \& Ladson, A. (1991). Digital terrain modelling:a review of hydrological,geomorphological and biological applications. Hydrological Processes, 5(1), 3-30.

Nefeslioğlu, H. A., Gokceoglu, C. \& Sonmez, H. (2008). An assesment on the use of logistic regression and artificual neural networks with different sampling strategies for the preparation of landslide susceptibility maps. Engineering Geology, 97(3-4), 171-191.

Negnevitsky, M. (2002). Artificial Intelligence A Guide to Intelligent Systems (2 b.). Great Britain: Addison-Wesley.

Okay, I., \& Şahintürk, Ö. (1997). Geolog of the Eastern Pontides. n A.G.Robinson(ed.) Rgional and petroleum of the Black Sea and surriounding region,AAPG Memoir.

OGM (2007). Orman Genel Müdürlüğü Amenajman Planı. Ankara.

Özdemir, A. (2008). Zemin Mekaniği ve Zemin Mühendisliğine Giriş. Konya: İnci Matbaas1.

Özsayar, T., Pelin, S., \& Gedikoğlu, A. (1981). Doğu Pondidlerde kretase. KTÜ Yerbilimleri Dergisi, 65-114.

Saha, A., Gupta, R., \& Arora, M. (2002). GIS-based landslide hazard zonation in Bhagirathi (Ganga) valley,Himalayas. Int.J.Remote Sensing, 23(2), 357-369.

Soeters, R., \& Van Western, C. (1996). Slope instability recognition, analysis and zonation. Transportation Research Board, National Research Council. Washington D.C.: National Academy Press.

Şaroğlu, F., \& Yılmaz, Y. (1986). Geological Evolution and Basin Models During Neotectonic Episode in the Eastern Anatolia. Maden Tetkik ve Arama Dergisi, 107(107), 70-93.

Tekin, S., \& Çan, T. (2019). Yapay Sinir Ağları Yöntemi ile Ermenek Havzası nın (Karaman) Kayma Türü Heyelan Duyarlılık Değerlendirmesi. Bilge International Journal of Science and Technology Research, 3(1), 21-28.

Tekin, S., Çan, T., \& Mazman, T. T. (2015). Doğu Akdeniz Bölgesinin Yapay Sinir Ağları Yöntemi İle Heyelan Duyarlılık Değerlendirmesi. MÜHJEO'2015: Ulusal Mühendislik Jeolojisi Sempozyumu, KTÜ, (s. 137-144). Trabzon.
Uzunsoy, M., \& Görcelioğlu, E. (1985). Havza Islahında Temel İlke ve Uygulamalar. İstanbul: İ .Ü.Orman Fakültesi Yayınları.

Wang, C. (1994). Theory of generalization in learning machines with neural application. USA: The University of Pennsylvania.

Web (2018). 9 12, 2018 tarihinde psilolojik.gen.tr: https://www. psikolojik.gen.tr/yapay-sinir-aglari.html adresinden alındı

Wilson, J., \& Gallant, J. (2000). Terrain Analysis :Principles and Applications (1 edition b.). Wiley.

Wythoff, B. (1993). Backpropagation neural networks: a tutorial. Chemometrics and Intelligent Laboratory Systems, 18(2), 115-155.

Varnes, D. (1978). Slope movement types and processes, in Schuster, R.L., and Krizek, R.J., eds., Landslides-Analysis and control. National Research Council, Transportation Research Board. Washington: National Academy of Sciences.

Yalçın, A. (2008). GIS-based landslide susceptibility mapping using analytical hierarchy process and bivariate statistics in Ardesen (Turkey):Comparisons of results and confirmations. Catena, 72(1), $1-12$.

Yeon, Y., \& Ryu, K. (2010). Landslide susceptibility mapping in Injae,Korea,Using a decision tree. Engineering Geology, 116(3-4), 274-283.

Yesilnacar, E., \& Topal, T. (2005). Landslide susceptibility mapping: a comparison of logistic regression and neural networks methods in a medium scale study, Hendek region. Engineering Geology, 79(3-4), 251-266.

Y1lmaz, I. (2009). Comparison of landslide susceptibility mapping methodologies for Koyulhisar, Turkey: conditional probability,logistic regression, artificial neural network and support vector machine. Environmental Earth Science, 61(4), 821-836.

Y1lmaz, I. (2010). The effect of the sampling strategies on the landslide susceptibility mapping conditional probability and artificial neural networks. Environmental Earth Science, 60(3), 505-519.

Yılmaz, I., Terlemez, İ., \& Uysal, Ş. (1998). Hınıs (Erzurum güneydoğusu) dolaylarının bazı stratigrafik ve tektonik özellikleri. MTA Dergisi, 108.

Yüksel, N. (2007). Coğrafi Bilgi Sistemleri Tabanlı Heyelan Duyarlılık Haritalarının Oluşturulmasında İstatistiksel Yöntemlerin ve Yapay Sinir Ağlarının Kullanılması: Kumluca-Ulus (Bartın) Bölgesi. Ege Coğrafya Dergisi, 23(2), 19-35. 